\title{
A neomorphic ossification of the nasal cartilages and the structure of paranasal sinus system of the glyptodont Neosclerocalyptus Paula Couto 1957 (Mammalia, Xenarthra)
}

\author{
Juan Carlos Fernicola, Néstor Toledo, M. Susana Bargo, and Sergio F. Vizcaíno
}

\begin{abstract}
Glyptodonts together with armadillos, pampatheres and peltephilines constitute the Cingulata, one of the three clades of the Xenarthra. The most remarkable feature of this group is the presence of an armored exoskeleton along the head, body and tail. Only a few contributions have described in detail the endoskeleton. In the case of the skull, almost no attention has been focused on the narial region. The objective of this study is to provide a description of the narial anatomy of the glyptodont Neosclerocalyptus. This genus has the most expanded and globular narial region among glyptodonts and was recently described as part of the fronto-nasal sinuses system. Our analysis based on CT scanning shows that this region includes an independent ossification of the nasal cartilage that housed the maxillo-atrioturbinates. This ossification would represent a neomorphic feature produced by a terminal addition of an ossified stage via peramorphosis. Other remarkable anatomical features are the presence of an expanded paranasal sinuses system that involves the nasal, frontal, parietal and squamosal bones, and the wide separation between the maxillo-atrioturbinates and ethmoturbinates. Functional consequences of this rearrangement are not readily predicted or inferred. Thus, this neomorphic ossification would constitute a morphological novelty, but not necessarily a functional one.
\end{abstract}

Juan Carlos Fernicola. CONICET - División Paleontología, Museo Argentino de Ciencias Naturales "Bernardino Rivadavia", Av. Ángel Gallardo 470, C1450DJR Ciudad Autónoma de Buenos Aires, Argentina. jctano@yahoo.com, jctano@macn.gov.ar and Universidad Nacional de Luján, Departamento de Ciencias Básicas, Ruta Nacional 5 y Av. Constitución, 6700 Luján, Argentina Néstor Toledo. División Paleontología Vertebrados, Museo de La Plata, Paseo del Bosque s/n, B1900FWA, La Plata, Argentina. CONICET. ntoledo@fcnym.unlp.edu.ar M. Susana Bargo. División Paleontología Vertebrados, Museo de La Plata, Paseo del Bosque s/n, B1900FWA, La Plata, Argentina. CIC. msbargo@fcnym.unlp.edu.ar Sergio F. Vizcaíno. División Paleontología Vertebrados, Museo de La Plata, Paseo del Bosque s/n, B1900FWA, La Plata, Argentina. CONICET. vizcaino@fcnym.unlp.edu.ar

Key words: cingulates; glyptodonts; nasal cavity; narial ossification; neomorphic; function

PE Article Number: 15.3.27A

Copyright: Palaeontological Association October 2012

Submission: 21 June 2012. Acceptance: 19 September 2012

Fernicola, Juan Carlos, Toledo, Néstor, Bargo, M. Susana, and Vizcaíno, Sergio F. 2012. A neomorphic ossification of the nasal cartilages and the structure of paranasal sinus system of the glyptodont Neosclerocalyptus Paula Couto 1957 (Mammalia, Xenarthra). Palaeontologia Electronica Vol. 15, Issue 3;27A,22p;

palaeo-electronica.org/content/2012-issue-3-articles/305-glyptodont-nasal-anatomy 

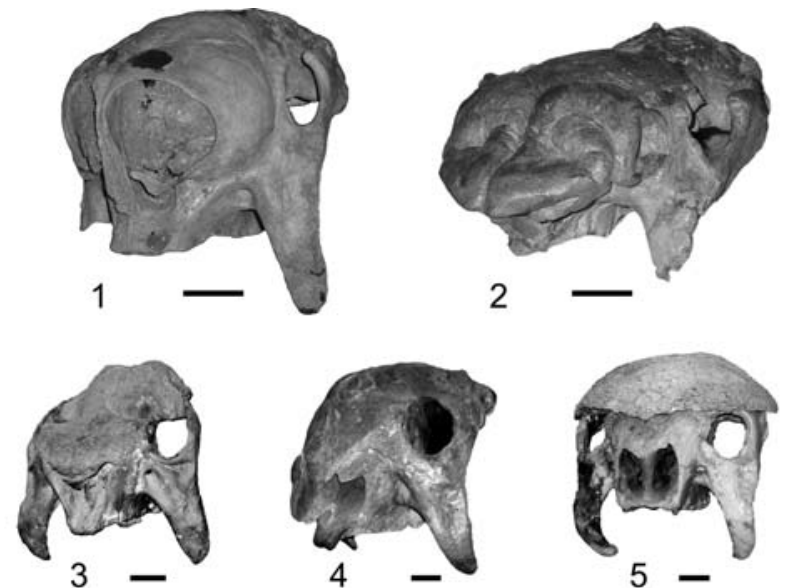

FIGURE 1. Skull of Pleistocene glyptodonts: 1- Neosclerocalyptus paskoensis (MACN-Pv 18107); 2- Neosclerocalyptus sp. (MACN-Pv 8091); 3- Glyptodon reticulatus (MACN-Pv 10153); 4- Panochthus tuberculatus (MLP 16-38); 5- Doedicurus sp. (MACN Pv. 2762). Scale bar equals $5 \mathrm{~cm}$.

\section{INTRODUCTION}

The glyptodonts (Xenarthra, Cingulata), comprising one of the most important groups of armored mammals that evolved in the Americas, are known from the middle Eocene to the Pleistocene-Holocene boundary (see Fernicola et al., 2008). During the Pleistocene, these herbivorous mammals attained their largest morphologic diversity and a high taxonomic richness (22 genera according to McKenna and Bell, 1997). All were large forms, ranging in body mass from several hundred kilograms to two tons (Fariña et al., 1998; De Esteban-Trivigno et al., 2008; Vizcaíno et al., 2011a, 2012), and possessed remarkable anatomical features with no functional analogues among living mammals that made glyptodonts a peculiar group. Such features include the presence of an essentially immobile dorsal carapace; hypselodont and mostly lobate teeth consisting of an external layer of cementum, a matrix of orthodentine and a raised central axis of harder osteodentine (Hoffstetter, 1958; Gillette and Ray, 1981; Fariña and Vizcaíno, 2001; Vizcaíno et al., 2004, 2011a, 2011b; Fernicola et al., 2008; Vizcaíno, 2009; Kalthoff, 2011); and a unique skull.

The skull morphology (Figure 1 ) is very different when compared with that of their extinct and living relatives, the armadillos (Figure 2.1): the cranium is dorsoventrally tall and anteroposteriorly short; the rostrum and the masticatory apparatus are positioned below the braincase, producing a very marked angle between the mandibular too-

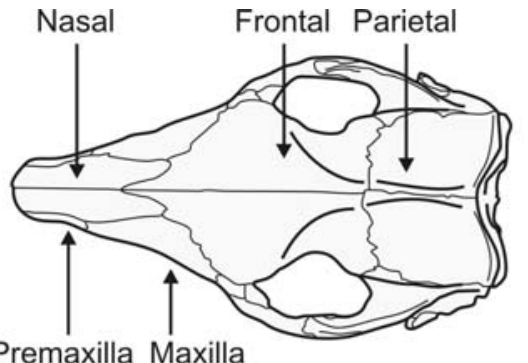

1
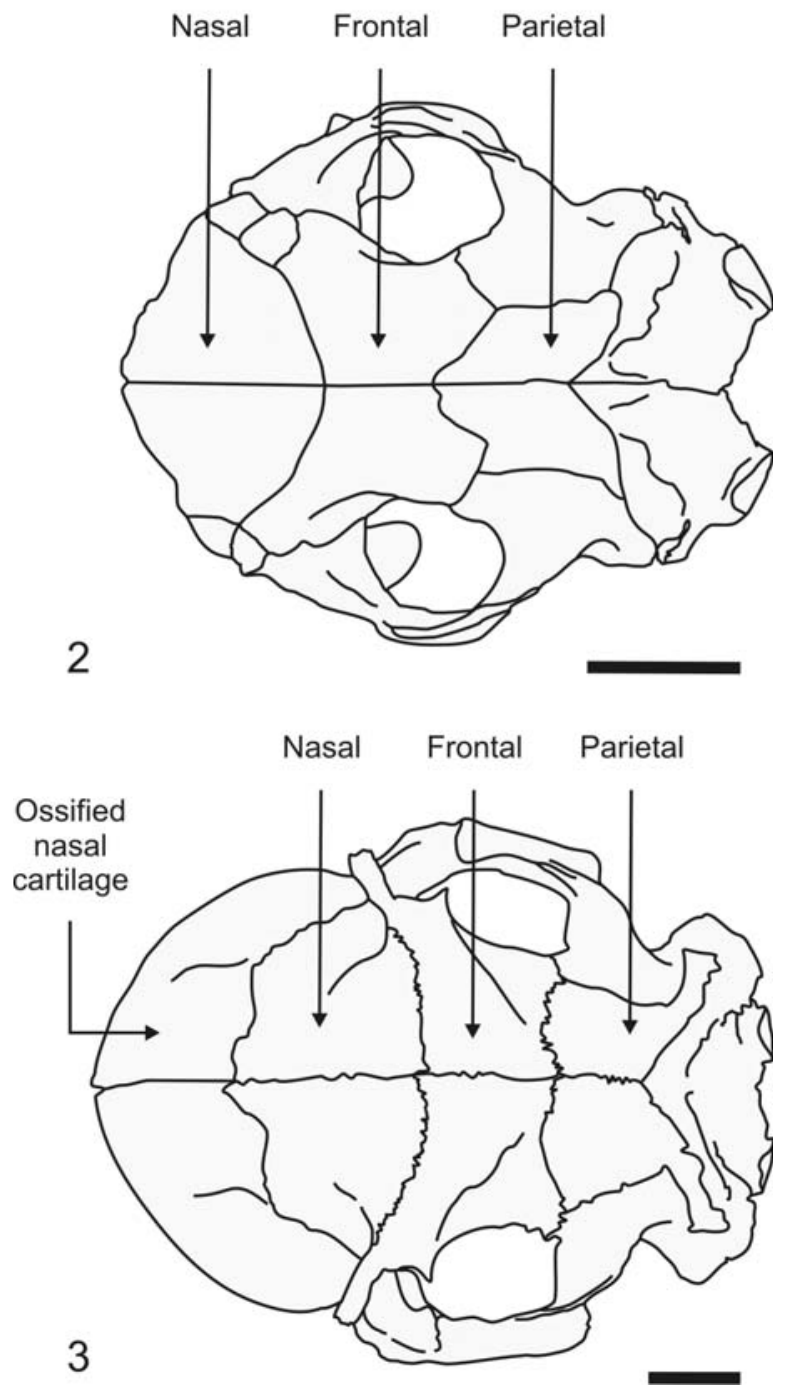

FIGURE 2. Skull of cingulates in dorsal view: 1- Chaetophractus sp.; 2- Glyptodon reticulatus (MACN-Pv 10153); 3- Neosclerocalyptus paskoensis (MACN-Pv 18107). Scale bar equals $5 \mathrm{~cm}$. 


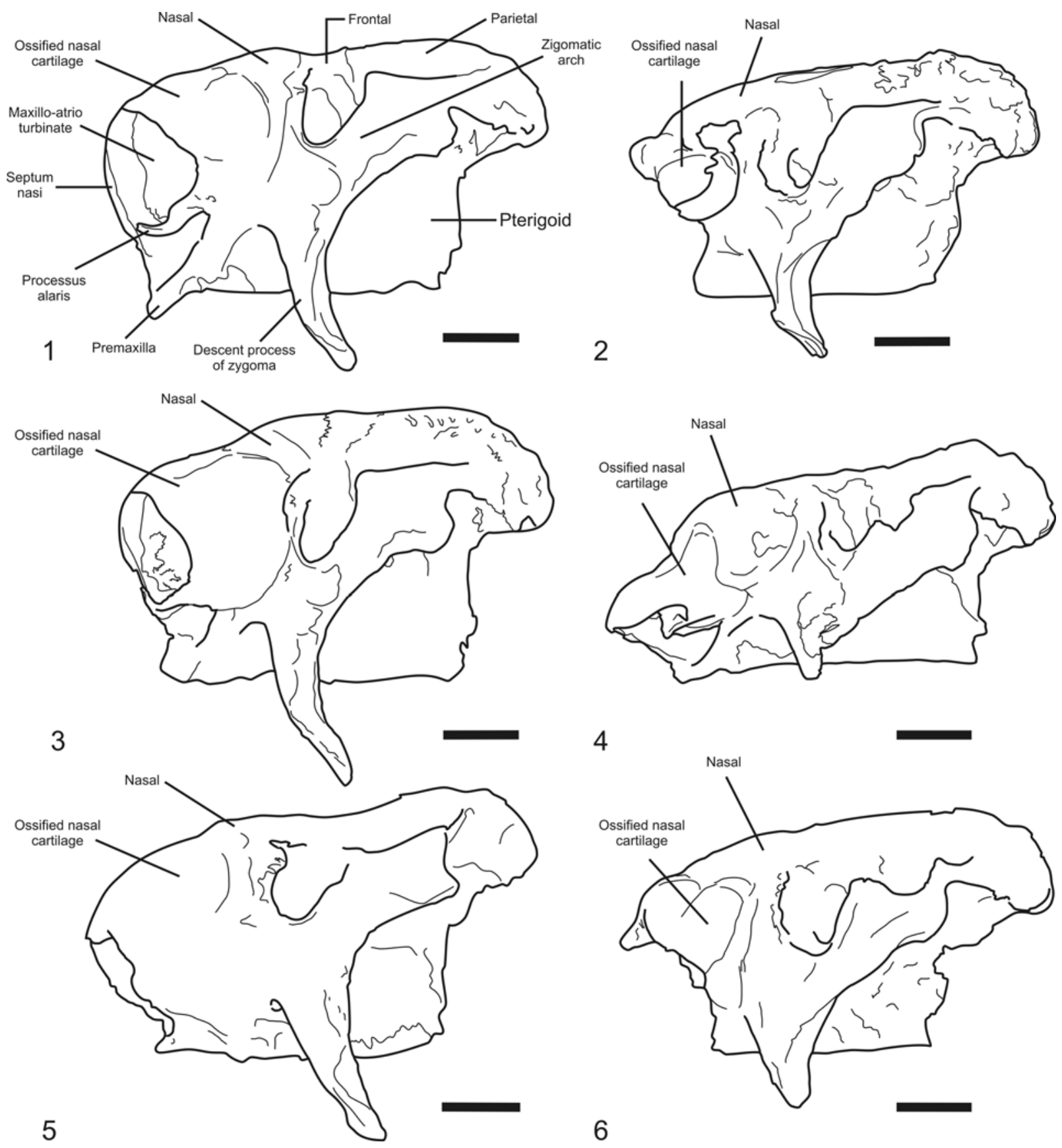

FIGURE 3. Skulls of Neosclerocalyptus in lateral view (nasal region to the left), showing different morphotypes: 1Neosclerocalyptus paskoensis (MLP 16-384); 2- Neosclerocalyptus pseudornatus (MACN-Pv 8579); 3- Neosclerocalyptus paskoensis (MACN-Pv 18107); 4- Nesoclerocalyptus sp. (MACN-Pv 8091); 5- Neosclerocalyptus ornatus (MLP 16-28); 6- Neosclerocalyptus pseudornatus (MACN-Pv 8773). Scale bar equals $5 \mathrm{~cm}$.

throw and the coronoid process; the zygomatic arch posseses a huge descending process that projects ventrally beyond the toothrow and is particularly important as an origin site of the masseteric musculature (Fariña and Vizcaíno, 2001; Vizcaíno et al., 2004).

Among glyptodonts, a particularly remarkable feature is the expanded and globular narial region
(Figures 1.1-1.2, 3) present only among specimens assigned to Neosclerocalyptus Paula Couto, 1957. The degree of expansion of the narial region is so marked that the orbits are directed almost entirely laterally, and probably precluded the animal's capacity for frontal vision.

Studies on the skull anatomy of glyptodonts are scarce, and those on the morphology of the 
nasal cavity even more so. Among them, we may note the descriptions of Huxley (1864) on Glyptodon Owen, 1839; Burmeister (1870-1874) on Glyptodon, Panochthus Burmeister, 1866, and Neosclerocalyptus; Scott (1903) on Propalaehoplophorus Ameghino, 1887, and Cochlops Ameghino 1889; and Gillete and Ray (1981) on Glyptotherium Osborn, 1903. Huxley (1864) provided a brief description of the posterior part of the nasal cavity. Burmeister (1870-1874) published a detailed description of the nasal cavity of Glyptodon based on at least two longitudinally and transversely sectioned skulls and considered also the skulls of NeOsclerocalyptus and Panochthus, in which the presence of frontal and parietal sinuses were verified. Huxley (1864) and Burmeister (1870-1874) recognized in Glyptodon the presence of frontal sinuses communicating with the nasal cavity. Burmeister (1870-1874) also identified the presence of several chambers in the skull roof of Neoscleocalyptus and Panochthus (although not illustrated in the latter) that he recognized as sinuses, but because of the fragmentary nature of the specimen he did not provide functional or other interpretations. Despite this singular morphology, this subject was completely abandoned as a course of study during the $20^{\text {th }}$ century. Recently, Zurita and collaborators revisited the topic of the nasal morphology of Neosclerocalyptus and attempted to explain its biological meaning (Zurita, 2002; Zurita et al., 2005, 2008, 2009, 2011). Based on their work and Burmeister's (1870-1874) descriptions, these authors interpreted the most anterior part of the narial bony expansion as sinuses within the nasal bone and its morphologic variation (Figure 3 ) as reflecting specific differences among the four species recognized by Zurita et al. (2011): N. pseudornatus (Ameghino, 1889), N. ornatus (Owen, 1845), N. gouldi Zurita et al., 2008, and N. paskoensis (Zurita, 2002). Conversely, preliminary studies by Fernicola et al. (2007), Toledo et al. (2007), and Fernicola et al. (2010) interpreted the most anterior part of the narial bony expansions in Neosclerocalyptus as the result of ossification of the nasal cartilages. The form of the external surface of the ossified nasal cartilage allows recognition of two main morphotypes: one a single globular structure and the other with at least two protuberances separated by grooves.

From the phylogenetic perspective, Zurita et al. (2011) suggested that narial ossification, despite the morphologic variation and the different interpretations on the anatomical parts involved, is a possible synapomorphy uniting the four species in a single clade, currently considered as Neosclerocalyptus. This genus was considered by Fernicola (2008), Porpino et al. (2010), and Fernicola and Porpino (2012) as the sister taxon of Hoplophorus Lund, 1839 plus Panochthus (Figure 4).

Zurita et al. (2011) also made some ecological assessments, suggesting a correlation between the degree of pneumatization of the skull and the cold arid Pleistocene cycles of South America (Clapperton, 1993).

The different interpretations of the anatomical parts of the narial expansions of Neosclerocalyptus indicate that more detailed research on the anatomy of the nasal cavity is needed. On this basis and proceeding along similar studies performed on living mammals by Witmer et al. (1999) and Clifford and Witmer (2004a, 2004b), we undertake extensive comparative anatomical analyses of the nasal cavity of the skulls of Neosclerocalyptus, as well as other glyptodont genera (Glyptodon, Panochthus and Doedicurus Burmeister, 1874), and evaluate its paleobiological significance. As specimens belonging to $N$. paskoensis are the best preserved, we initiate the series of planned contributions by providing a detailed anatomical description of the skull roof and nasal cavity of this species and discussing its functional implications.

\section{MATERIAL AND METHODS}

\section{Materials}

Institutional acronyms. AGM: Archivo Gráfico y Museo Histórico de la Ciudad de San Francisco y alrededores, Córdoba Province, Argentina; MCA: Museo de Ciencias Naturales "Carlos Ameghino", Mercedes, Buenos Aires Province, Argentina; MLP: Museo de La Plata, La Plata, Buenos Aires Province, Argentina; MACN-Pv: Colección Nacional de Paleontología de Vertebrados del Museo Argentino de Ciencias Naturales "Bernardino Rivadavia", Ciudad Autónoma de Buenos Aires, Argentina.

\section{Neosclerocalyptus gouldi}

MCA 2010. Skull and cephalic shield, humerus and fragmentary dorsal carapace. Horizon: Buenos Aires Formation / Bonaerian Stage (Zurita et al., 2009). Locality: San Andrés de Giles, Buenos Aires Province, Argentina.

\section{Neosclerocalyptus ornatus}

AGM 006. Partial skull, fragment of dorsal carapace, vertebrae and scapula. Horizon: Level 2 I Ensenadan Stage (Cruz et al., in press). Locality: 


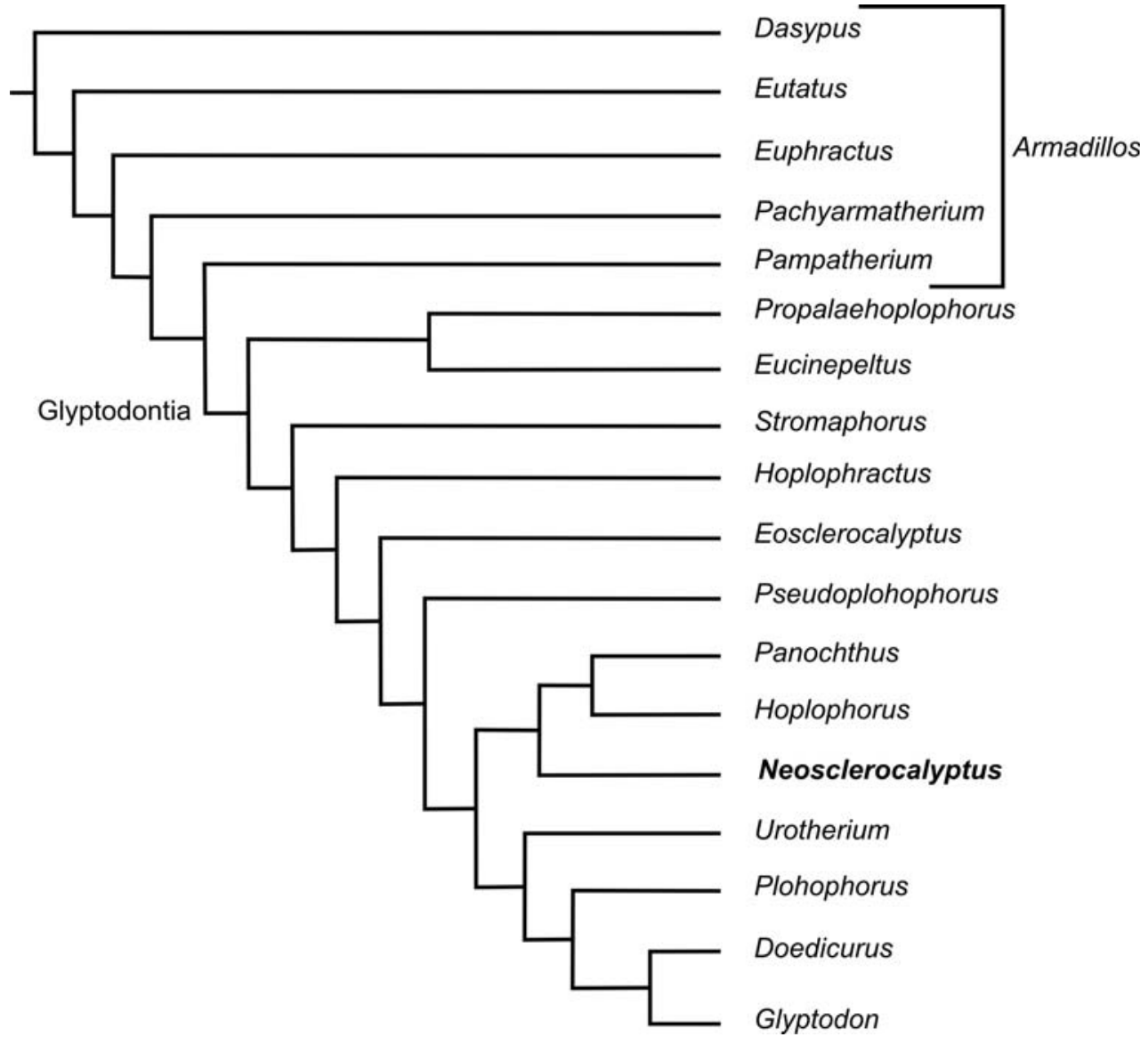

FIGURE 4. Cladogram depicting phylogenetic hypothesis used in this work. Modified from Fernicola (2008), Porpino et al. (2010), and Fernicola and Porpino (2012).

Cava de Carobolante, San Francisco, Córdoba Province, Argentina.

MLP 16-28. Complete skeleton. Horizon: Miramar Formation / Ensenadan Stage (Zurita et al., 2009). Locality: Mar del Plata, Buenos Aires Province, Argentina.

\section{Neosclerocalyptus paskoensis}

MLP 16-384. Skull and mandible. Horizon: Unknown. Locality: Unknown.

MACN-Pv 18107. Skull, mandible, fragment of dorsal carapace, cephalic shield, forelimbs and hind limbs. Horizon: Unknown. Locality: Carhué, Buenos Aires Province.

\section{Neosclerocalyptus pseudornatus}

MACN-Pv 8579. Skull without the most anterior part of the ossified nasal cartilages and mandible. Horizon: "Toscas del Río de La Plata" / Ensenadan Stage. Locality: Río de La Plata, Olivos, Buenos Aires Province, Argentina.
MACN-Pv 8773. Skull without the most anterior part of the nasal cavity, cephalic shield and fragment of dorsal carapace. Horizon: "Toscas del Río de La Plata" / Ensenadan Stage. Locality: Río de La Plata, Olivos, Buenos Aires Province, Argentina.

\section{Neosclerocalyptus sp.}

MACN-Pv 15151. Skull. Horizon: Unknown. Locality: Unknown.

MACN-Pv 8091. Skull. Horizon: Miramar Formation / Ensenadan Stage (Zurita et al., 2011). Locality: Mar del Plata, Buenos Aires Province, Argentina. Zurita et al. (2011) considered this fossil as a deformed specimen of $N$. ornatus. However, the bilaterally symmetric position of the anatomical elements indicates that it is not a heavily distorted specimen (Figure 1.2).

\section{Methods}

For the purposes of this work, we describe mainly the skull roof and the osseous elements that 
contribute to the formation of the nasal cavity of $N$. paskoensis. In doing so, we first analyze the skull morphology of different Pleistocene glyptodonts: Glyptodon, Panochthus and Doedicurus and the other specimens of Neosclerocalyptus. The external cranial anatomical terminology used herein for adult individual follows Gillete and Ray (1981) and Wible and Gaudin (2004), who described the skull of the glyptodont Glyptotherium and the armadillo Euphractus sexcinctus (Linnaeus, 1758), respectively. For recognition of paranasal sinuses we follow the terminology provided by Farke (2010). This author considered a sinus as an air-filled cavity within the bone, generated by the removal of trabecular bone by the activity of soft tissues of the nasal cavity. Therefore, this space is positioned between two layers of cortical bone. In contrast, a recess is a concavity of the surface of the bone. With respect to the identification of features of the nasal cavity, we follow Reinbach (1952a, 1952b, 1955), Wegner (1960) and Zeller et al. (1993) (see "Discussion").

To evaluate the internal anatomical structures of the nasal cavity, MACN-Pv 18107 was subjected to $X$-ray computered tomographic (CT) scanning at the Hospital "Dr. Diego Paroissien" in La Matanza, Buenos Aires, Argentina. Slice thickness for MACN-Pv 18107 was $1 \mathrm{~mm}$. CT scanning provided good resolution between bone and rock matrix.

\section{RESULTS}

\section{Skull Roof and Nasal Cavity Morphology of Neosclerocalyptus paskoensis}

In contrast to the condition in most adult specimens of other glyptodonts, in which many sutures of the skull are obliterated during ontogenetic development (hindering recognition of the different bony elements), in specimens of $N$. paskoensis (MACN-Pv 18107) and N. pseudornatus (MACN 8579) the sutural boundaries are preserved in the adult stage, allowing recognition of bone limits. This peculiar condition allows us to delimit the extension of the supraoccipital, parietal, frontal and nasal bones, as well as a fifth osseous element, the posterior border of which is overlapped dorsally by the nasal bones (Figure 2.3). The premaxillae and maxillae overlap this fifth element ventrally and laterally. The walls of this latter element are composed of external and internal compact layers and a middle trabecular layer. As described later, this ossification housed the maxilla maxilloturbinates and atrioturbinates. We interpret this fifth element as an independent bone formed by the ossification of the nasal cartilages. This structure is not an exceptionally preserved artifact of taphonomic processes, but a bony element formed during the animal's life. In order to avoid the introduction of a new term for this element, we will refer to it as "ossified nasal cartilages" throughout the text.

\section{Skull in Dorsal View (Figure 2)}

Supraoccipital. In dorsal view this bone is represented by a narrow, transverse surface of approximately $10 \mathrm{~mm}$ width. Anteriorly it contacts both the parietals bones along a V-shaped suture, while laterally it contacts the mastoid exposure of the pars canalicularis of the petrosal bone.

Parietals. In dorsal view each parietal is $\Gamma$-shaped (Greek uppercase letter gamma). Laterally, its posterior narrow transverse arm contacts posteriorly the mastoid surface of the pars canalicularis of the petrosal bone and anteriorly it does the same with the posterior edge of the squamosal bone, both along straight sutures. Medially, the broad longitudinal arm contacts the contralateral parietal and laterally the medial edge of the squamosal, both along straight sutures, whereas its anterior edge contacts the frontal along an anteriorly convex suture. Most of the sutures are more or less horizontal, but those with the squamosal and petrosal are at right angles, as these bones are restricted to the side wall of the skull. Internally, each parietal bone contains a large parietal sinus, which is continuous with both the squamosal and frontal sinuses (see below).

Frontals. In dorsal view each frontal is rectangular, with the long axis oriented transversely. The short, medial margin contacts the contralateral frontal, and, similarly to the parietal, its lateral margin contacts the squamosal. Anterolaterally, the frontal contacts the lacrimal along a short, straight suture, while anteriorly it does the same with the nasal bone, though along a long and posteriorly concave suture. Internally, each frontal contains four sinuses, which are continuous with the sinuses of the parietals, squamosals and nasals (see below).

Lacrimals. In dorsal view each lacrimal is very small and rectangular. Posteriorly it contacts the frontal and medially the nasal. Its anterior margin overlaps the ossified nasal cartilages (see below). In the orbital side there is a wide lacrimal foramen and a lacrimal sinus is absent.

Nasals. In dorsal view each nasal is triangular, with a straight medial base and convex anterior and posterior edges. Medially, its longitudinal edge contacts the contralateral nasal. Together, the bones 


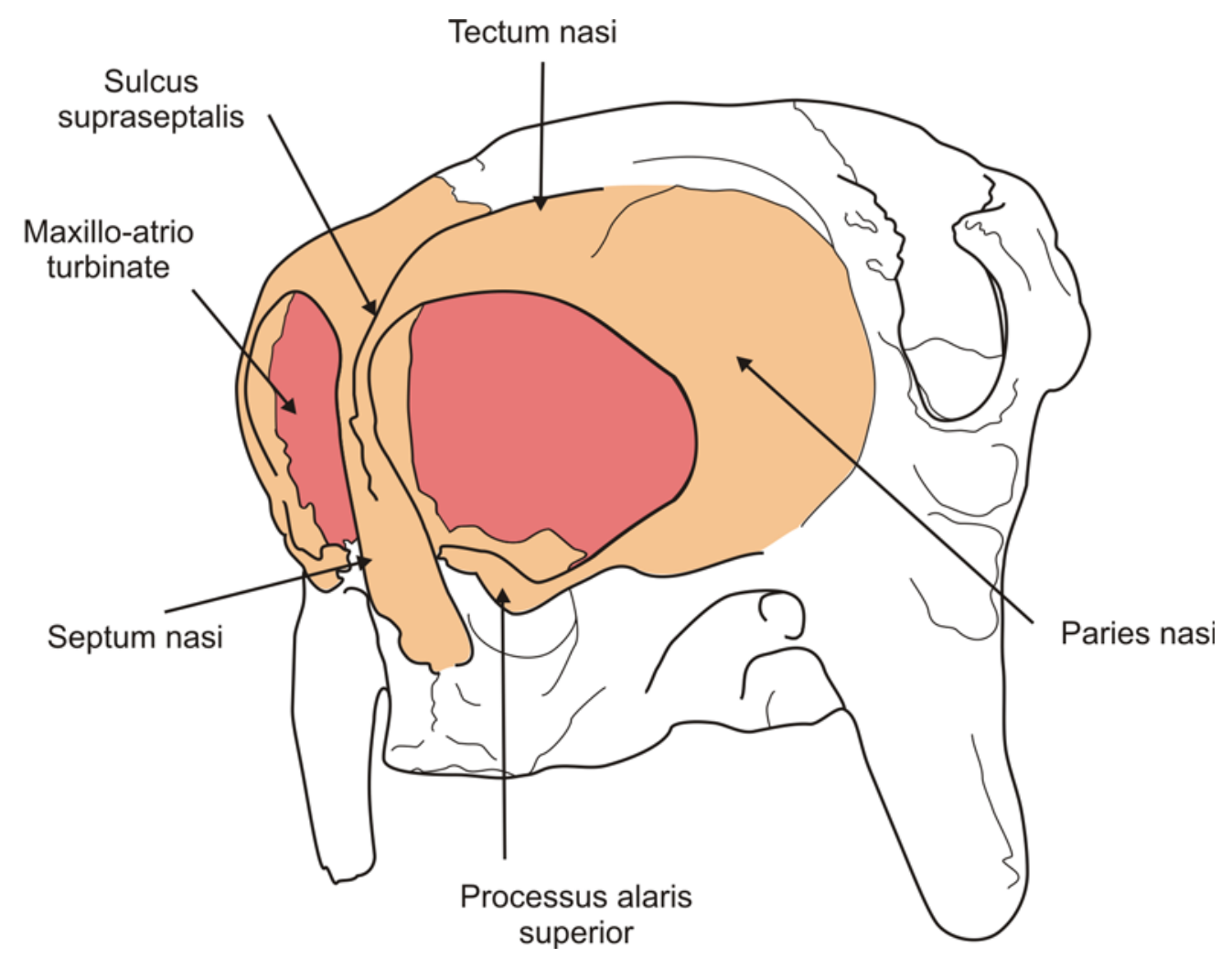

FIGURE 5. Skull of Neosclerocalyptus paskoensis (MACN-Pv 18107) depicting ossified nasal cartilages conforming the rostral most region (light orange) and turbinates (red).

outline an oval, with the major axis transverse to the sagital plane. Posteriorly each nasal contacts the frontal bones and laterally a lacrimal. Anteriorly, the nasals overlap the ossified nasal cartilages (Figures 5, 6). Each nasal contains three sinuses, of which one appears to be independent whereas the other two sinuses are continuous with the frontal sinuses (see below).

Ossified nasal cartilages. In dorsal view this element is globular in form and represents nearly one quarter of total skull length. Its osseous walls, lacking air cavities, are formed by a trabecular middle layer between inner and outer layers of cortical bone. Posteriorly it is overlapped by the nasals and dorsolaterally by the lacrimals. Ventrally and laterally to these latter contacts (Figure 5), the contribution of the maxillae and premaxillae could not be determined because their sutural contacts are obliterated. Each region of overlap is indicated by a narrow space, possibly occupied in life by connective tissue. The anterior border of the ossified nasal cartilages is acute and forms the osseous dorsal and lateral rim of the fenestra narina, which is delimited ventrally by the lamina transversalis anterior. Thus, the apertura piriformis is in fact the fenestra narina. The external surface is smooth and globular, without discontinuities (such as the fenestra lateralis), allowing recognition of the posterior limit of the cupula nasi anterior as defined in prenatal individuals of Cingulata (Fawcett, 1919, 1921; Reinbach, 1952a, 1952b, 1955; Wegner, 1960; Zeller et al., 1993). The only structure that we could differentiate is the processus alaris superior, positioned on the ventrolateral corner of the paries nasi.

\section{Paranasal Sinuses}

The paranasal sinuses (Figures 6-11), housed within the parietals, squamosals, frontals and nasals, are extensively interconnected by several apertures (following Márquez et al., 2008). Considered as a whole, the air space conformed delimited by these bones roughly resembles an inverted truncated pyramid. Topographically, it may be inferred that the anterior plane of this pyramid, contiguous with the posterior portion of the ossified nasal cartilages, would be formed entirely by the nasals. The ventral plane, in fact the roof of the nasopharyngeal duct, is formed by the internal cortical layer of the nasals and frontals. The posterior plane, coinciding with the roof of the ethmoid 


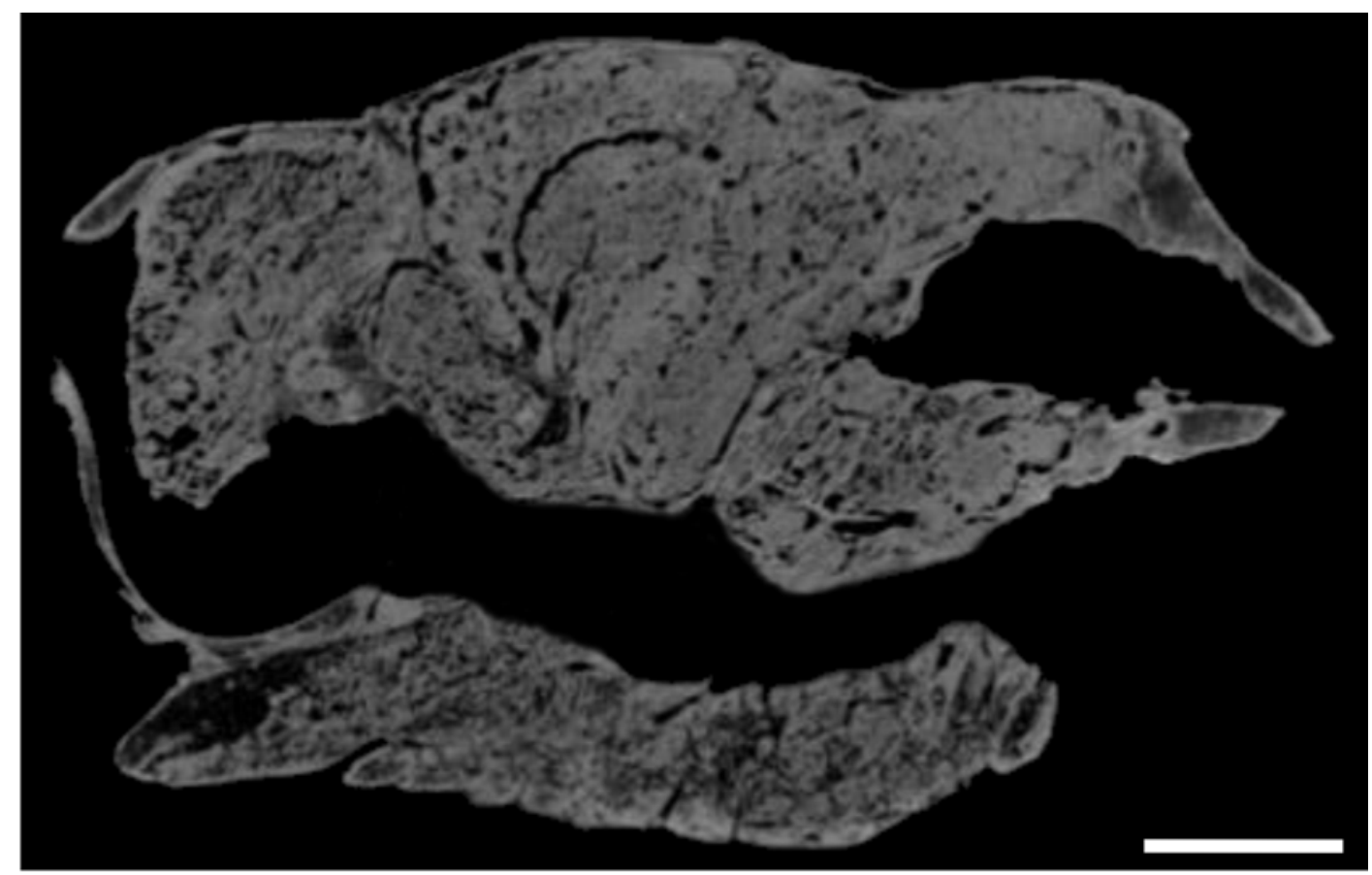

Overlapping of nasal bone over ossified nasal cartilage

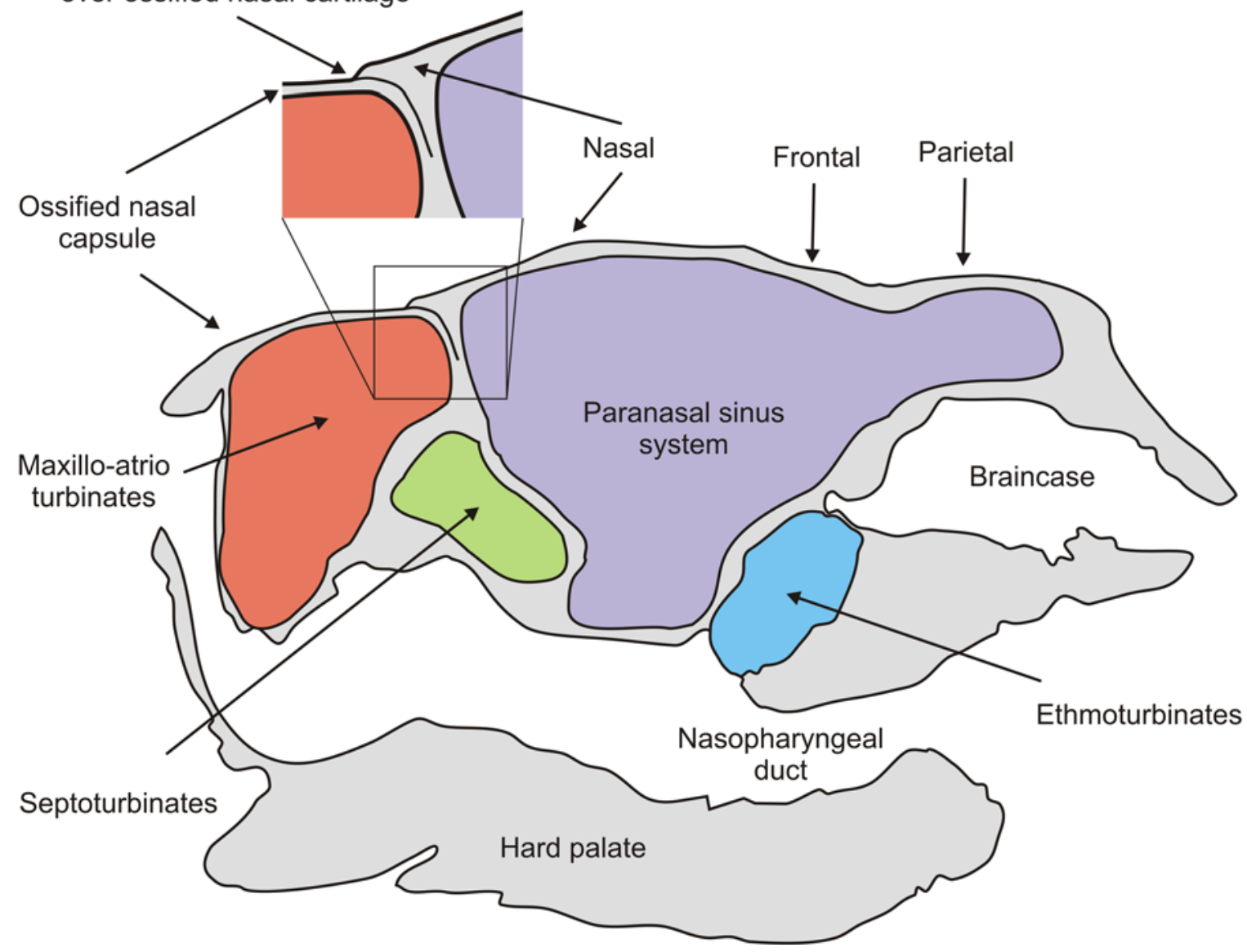

FIGURE 6. Neosclerocalyptus paskoensis (MACN-Pv 18107). Parasagittal CT slice (above) and diagram depicting structures explained in the text (below). Scale bar equals $5 \mathrm{~cm}$. 

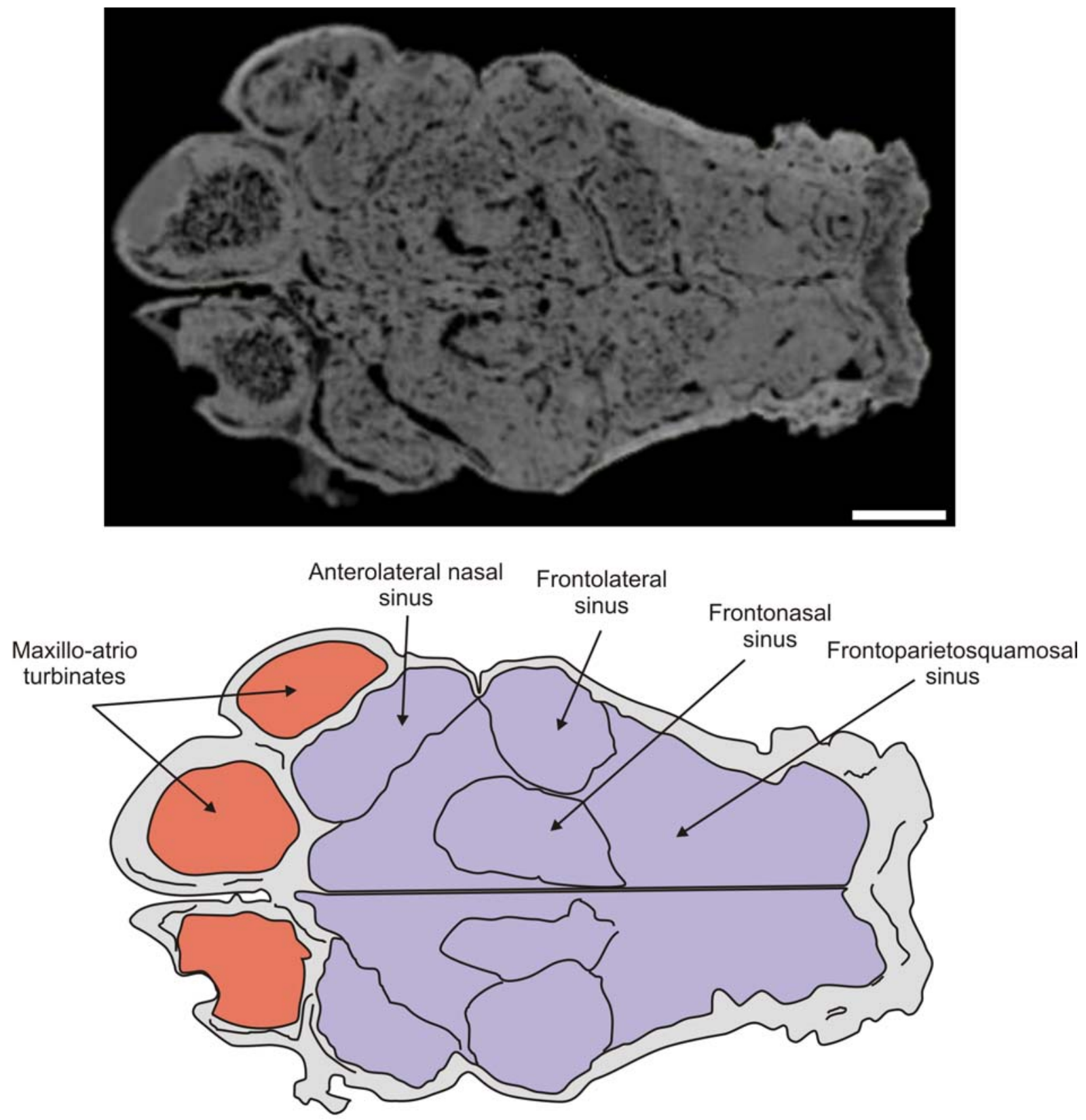

FIGURE 7. Neosclerocalyptus paskoensis (MACN-Pv 18107). Frontal CT slice (above) and diagram depicting paranasal sinuses explained in the text (below). Scale bar equals $5 \mathrm{~cm}$.

chamber and braincase and adjoining the anterior wall of occipitals, is formed by the internal cortical layer of the frontals and parietals. Laterally, the pyramid is formed by the internal layer of the lacrimals, frontals and squamosals. The internal cortical layer of the squamosal delimits the cranial cavity laterally. Finally, the dorsal plane of the pyramid is formed by the nasals, frontals and parietals, plus a small medial fringe of the squamosal region of the temporal.
The median longitudinal walls of both nasals, frontals and parietals divide the paranasal sinuses (the truncated pyramid) into symmetric right and left halves. Each half is subdivided by four main osseous walls that delimit the anterolateral nasal, frontolateral, frontonasal and frontoparietosquamosal sinuses. As occurs in several mammals (e.g., bovids, see Farke, 2010), the limits of the paranasal sinuses and the external boundaries of the cranial bones do not match precisely. 


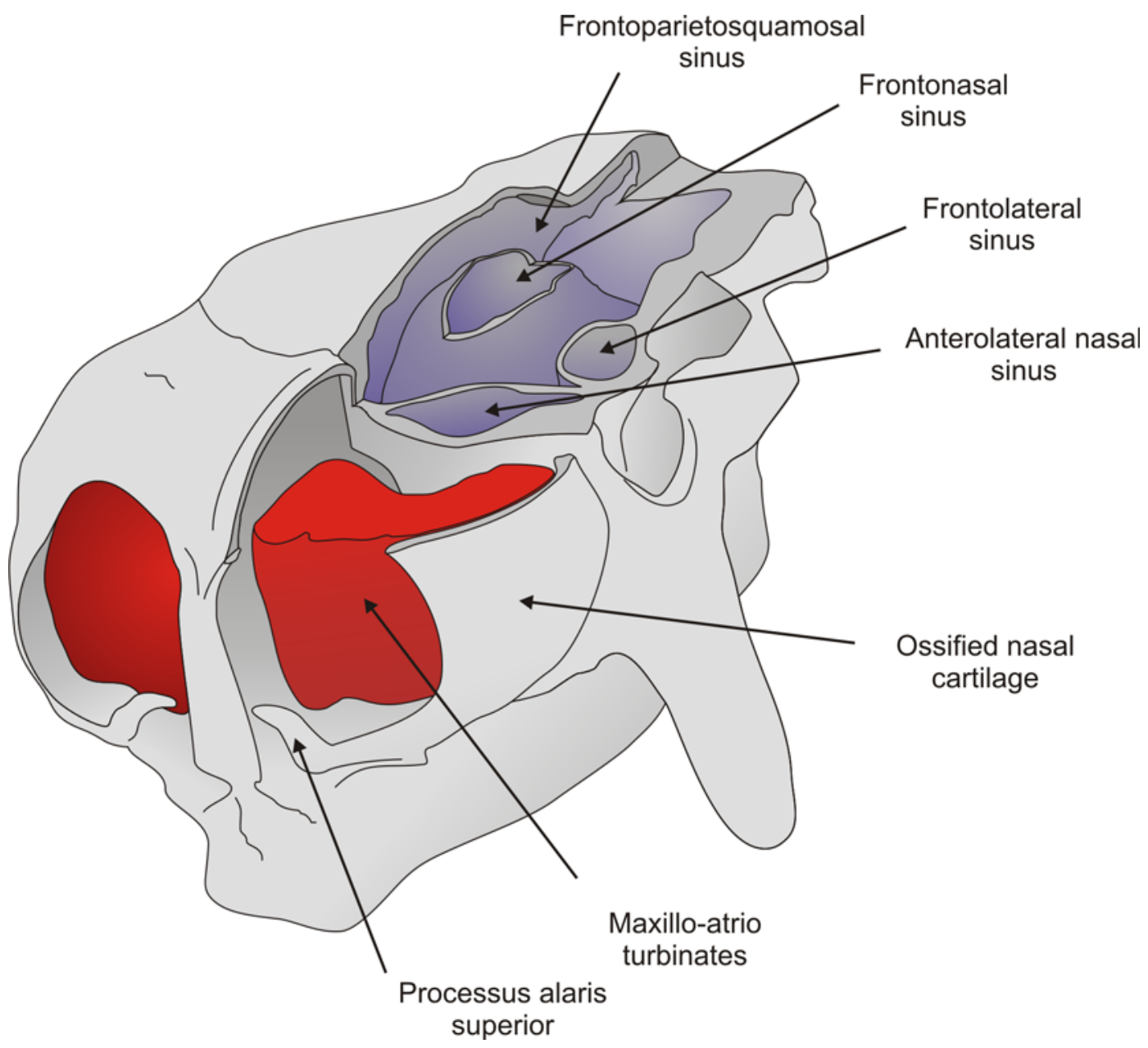

FIGURE 8. Neosclerocalyptus paskoensis (MACN-Pv 18107). Block diagram depicting paranasal sinuses explained in the text.

The dorsal part of the nasopharyngeal duct contains a very dense mass of sediment: its poor resolution in the CT scans precludes recognition of the openings through which the paranasal sinuses communicate with the nasopharyngeal duct.

Anterolateral nasal sinus. This kidney-shaped air cavity occupies most of the anterior and lateral portion of the nasal (Figures 7, 8). It is delimited dorsally by the external cortical layer of the nasal, anteriorly by the nasal's anterior wall (contacting the posterior surface of the ossified nasal cartilages), laterodorsally by the inner wall of the lacrimal bone and lateroventrally by the lateral wall of the maxilla. The posterior wall is formed by an anteriorly concave septum that is $55 \mathrm{~mm}$ thick. The length of the sinus from the anterior to the posterior wall is about $35 \mathrm{~mm}$. This posterior wall extends from the lateral wall of the skull to the median wall of the nasal approximately $25 \mathrm{~mm}$ from the skull midline. Ventrally, about $40 \mathrm{~mm}$ from the skull roof and aligned with the dorsal surface of the septoturbinates (see below), the posterior wall bends toward the anterior wall of the nasal bone, thus closing the anterolateral nasal sinus. However, a wide aperture located on its posteromedial portion communicates with the frontonasal paranasal sinus.

Frontolateral sinus. This oblong air cavity is housed within the anterior and lateral portions of the frontal (Figures 7, 8). Its dorsal boundary is formed by the ventral surface of the endocranial layer of the frontal. Anteromedially and posteromedially, the sinus is delimited by two walls that separate it, respectively, from the anterolateral nasal and the frontoparietosquamosal sinuses. About 22 $\mathrm{mm}$ from the dorsal boundary of the frontolateral sinus, each wall is pierced by a wide aperture (approximately $14 \mathrm{~mm}$ in height) through which the frontolateral sinus communicates with the frontonasal and frontoparietosquamosal sinuses. Ventral to 

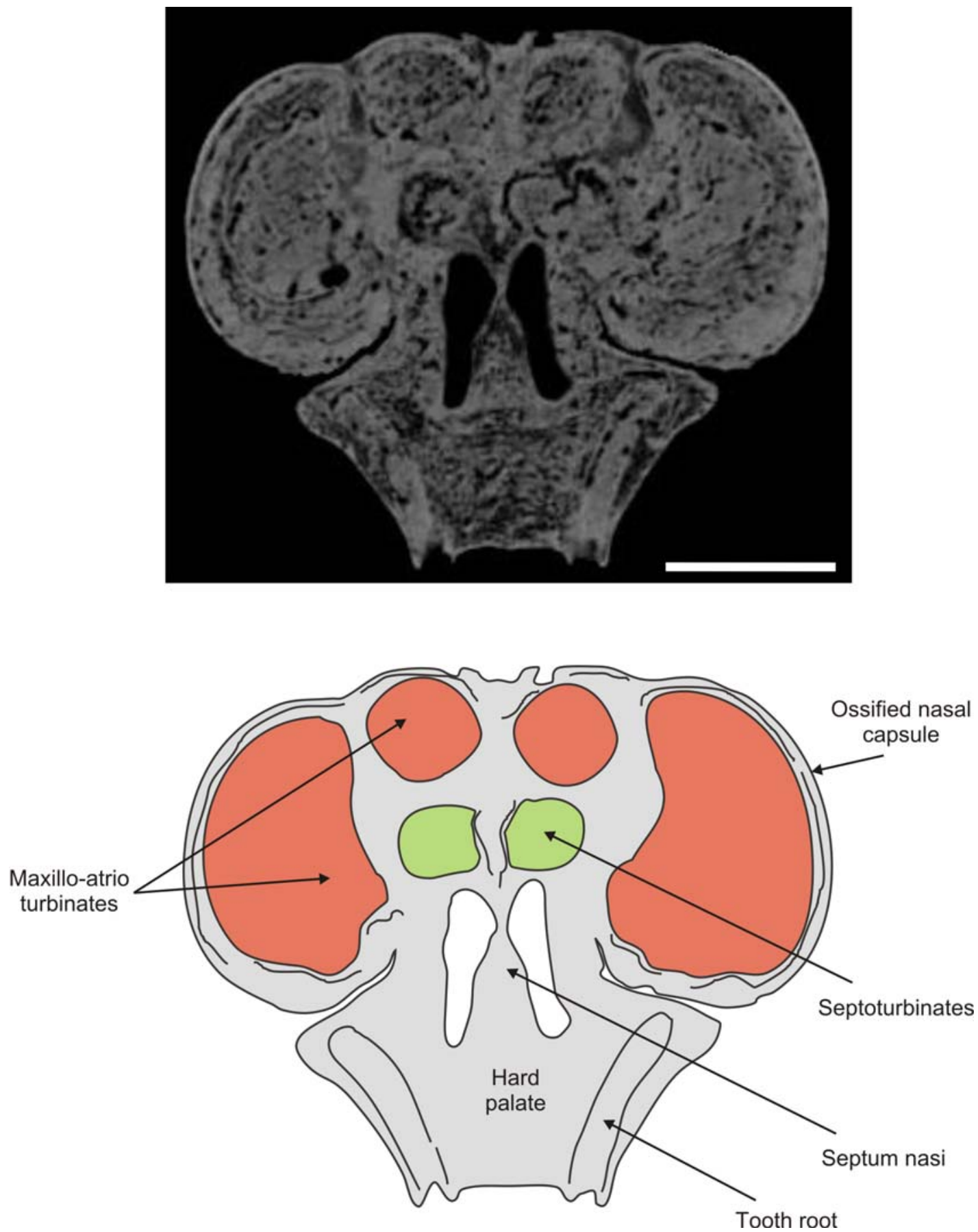

FIGURE 9. Neosclerocalyptus paskoensis (MACN-Pv 18107). Transverse CT slice (above) and diagram depicting structures explained in the text (below). Scale bar equals $5 \mathrm{~cm}$.

these apertures the walls converge and enclose the frontolateral sinus ventrally. The height of the sinus is approximately $45 \mathrm{~mm}$.

Frontonasal sinus. This oblong shaped air cavity occupies about two thirds of the inner space of the nasal and one quarter of the frontal bones (Figures $7,8)$. Its anterior surface rests on the posterior wall of the ossified nasal cartilages, whereas its posterior surface is constituted by the anterior wall of the frontoparietosquamosal sinus. It is delimited medially by the longitudinal median wall and laterally by the medial wall of the anterolateral nasal and frontolateral sinuses. Its ventral boundary is formed by the roof of the nasopharyngeal duct. From between 

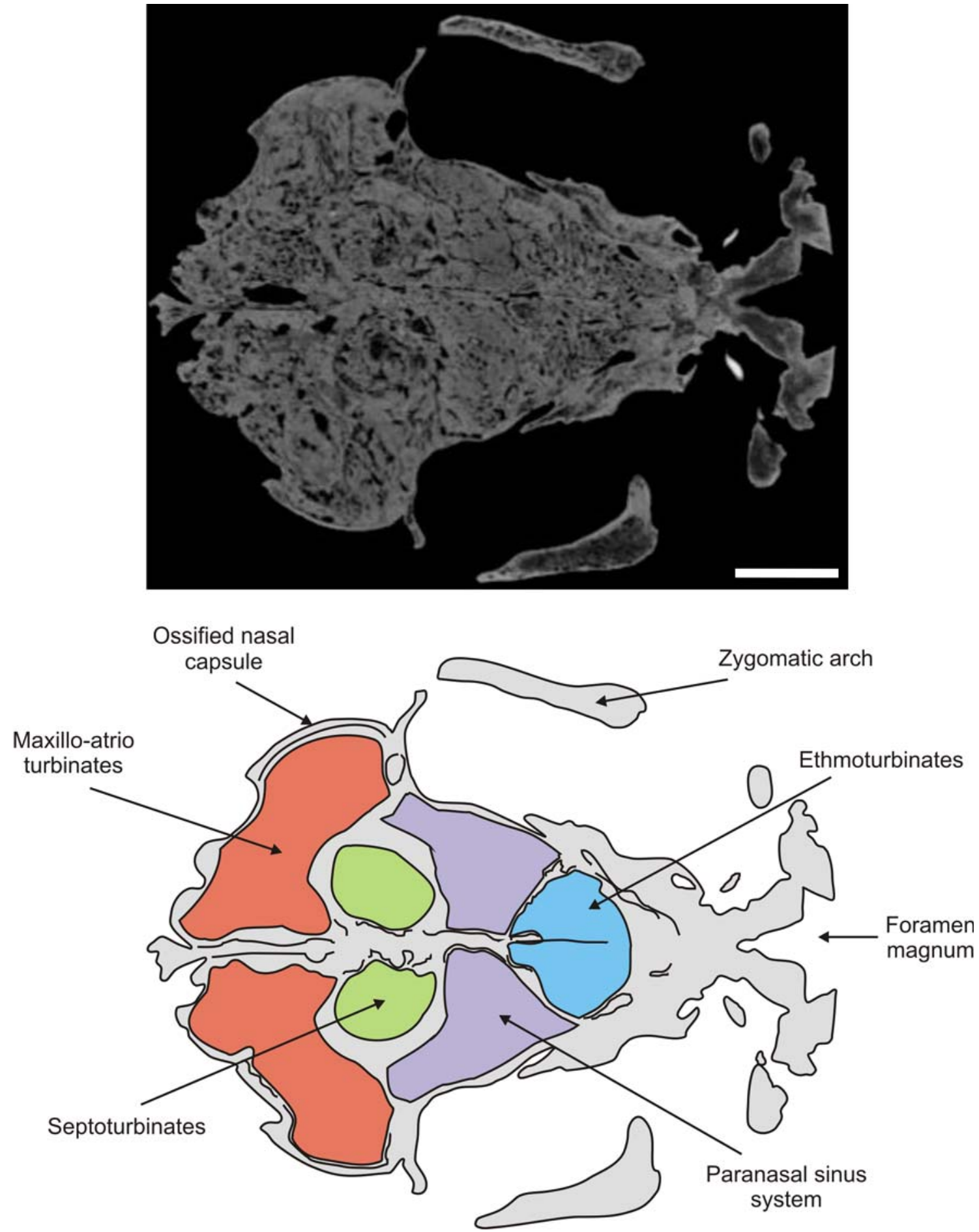

FIGURE 10. Neosclerocalyptus paskoensis (MACN-PV 18107). Frontal CT slice (above) and diagram depicting structures explained in the text (below). Scale bar equals $5 \mathrm{~cm}$.

approximately 22 to $46 \mathrm{~mm}$ ventral to the skull roof, an extensive, though incomplete dorsally convex, partition is developed and extends horizontally across the sinus between the median longitudinal wall and the medial walls of the anterolateral nasal and frontolateral sinuses. This partition subdivides this sinus into dorsal and ventral intercommunicated vaults.

Frontoparietosquamosal sinus. This air cavity occupies the dorsal third of the posterior half of the 


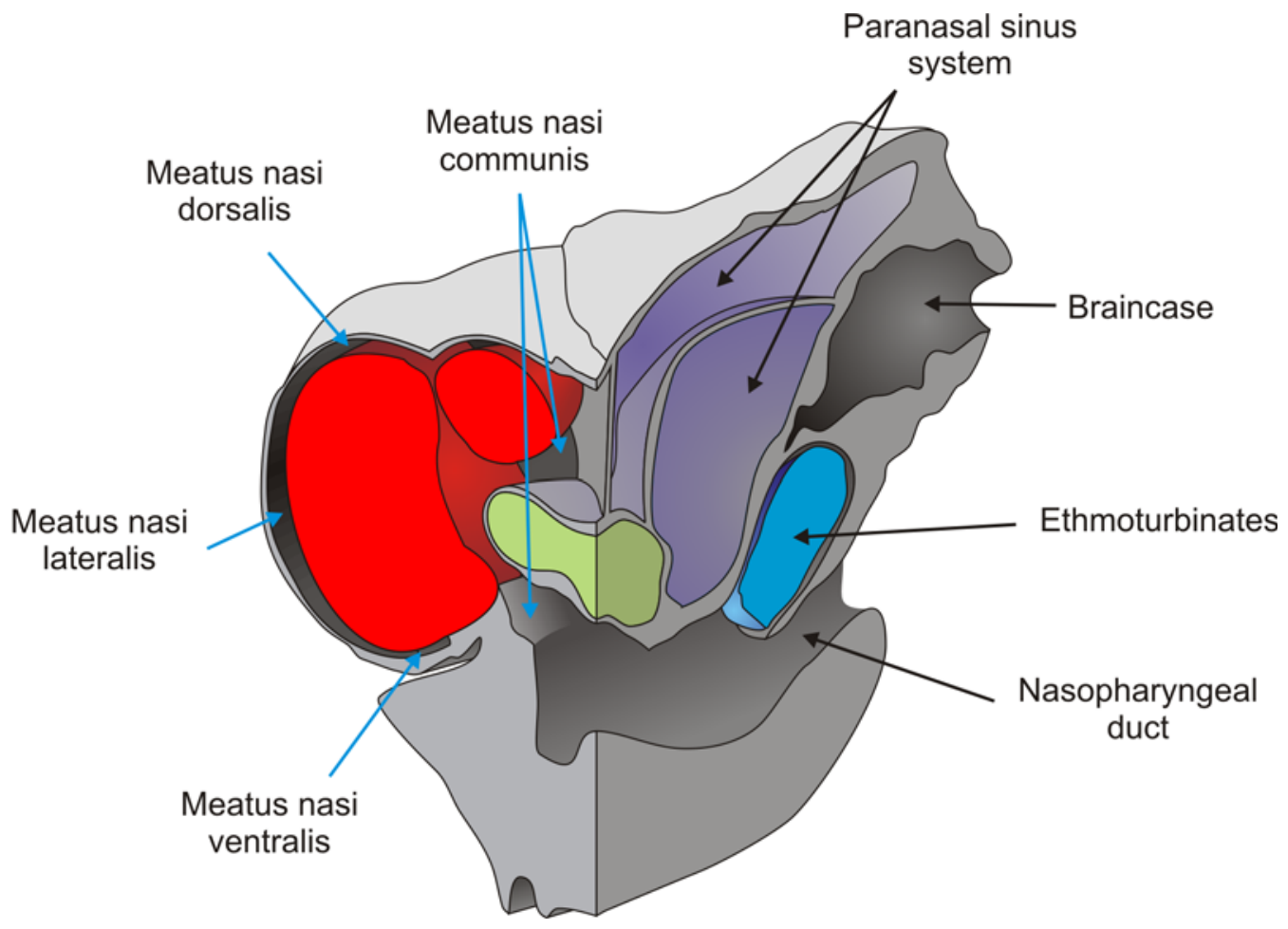

FIGURE 11. Neosclerocalyptus paskoensis (MACN-Pv 18107). Block diagram depicting nasal meatuses explained in the text.

frontal, and the entire parietal and squamosal (Figures 7,8$)$. It is delimited dorsally by the ventral surface of the external cortical layer of these three bones. Its lateral boundary is the inner surface of the external wall of squamosal. It is separated anteriorly from the frontonasal sinus by an osseous wall, although an aperture is present ventrally between these sinuses. The posterior surface of this wall bears a globular, open chamber. The sinus is limited posteriorly by the inner layer of the parietal, the roof of the braincase and of the ethmoid chamber. Internally, a parasagital partition that is continuous dorsally with the parietosquamosal suture and extends ventrally and obliquely to reach the roof of the braincase. The partition separates the sinus into parietal and squamosal portions, which extend anteriorly into the frontal portion of this sinus.

\section{Nasal Cavity}

Anterior portion. This portion is formed entirely by the ossification of the anterior part of the nasal cartilages (Figure 5), which form an anteroturbinate chamber. The absence of the fenestra lateralis prevents recognition of the posterolateral limits of the cupula nasi anterior. Thus, we describe, among the ossified nasal cartilages, the tectum nasi, solum nasi and paries nasi, and the processus alaris superior, positioned on the ventrolateral corner of the paries nasi. The apertura nasi externa is located between the processus and the cupula nasi anterior (Figure 5) (Göbbel, 2000 and references therein).

Ossified tectum nasi. The roof of the nasal capsule or tectum nasi (Figure 5) is convex in form and exhibits a deep groove along the midline that Fawcett (1919) termed the sulcus dorsalis nasi (= sulcus supraseptalis of Reinbach, 1952a, 1952b, 1955; Wegner, 1960). Dorsally, this groove separates the ossified nasal cartilages into symmetric left and right halves and extends about $15 \mathrm{~mm}$ anteroventrally, reaching the dorsal border of the ossified septum nasi. On the surface of the tectum nasi, approximately $40 \mathrm{~mm}$ from the sulcus, lies an obliquely oriented depression that is $25 \mathrm{~mm}$ in length and $10 \mathrm{~mm}$ in width. The anterior margin of the depression is about $25 \mathrm{~mm}$ from the anterior border of the ossified nasal cartilages, while its posterior margin reaches the anterior border of the nasal (Figure 5). The depression demarcates the position of an internal air space positioned between two posterior partitions of the maxillo-atrioturbinates (see below), but it is not possible to discern the presence of an internal partition in this 
space. A narrow space for air circulation is present between the inner surface of the tectum nasi and the maxillo-atrioturbinate. The boundary between tectum and paries nasi is indistinguishable. We thus consider, for descriptive purposes, the abovementioned depression as the limit between them. A notable feature is the absence of nasoturbinates, scroll-like bony structures that hang from the roof of the nasal cavity in most mammals, including other glyptodont genera (Gaudin and Wible, 2006; Gavrilov, 1959).

Ossified paries nasi. This corresponds to the lateral wall of the nasal (Figure 5). Its external surface is convex and bears on its ventroanteromedial corner a projection that plausibly represents a processus alaris superior, as defined by Göbbel (2000). This laminar process is triangular in form; its ventral half is directed upwards and extends dorsally, and its dorsal end extends toward the septum nasi. Its most distal border is about $5 \mathrm{~mm}$ from the septum nasi. The process almost completely divides the fenestra narina into dorsal and ventral portions, the functional interpretation of which is discussed in the next section. The inner surface of the paries nasi bears an extended osseous lamina that represents the anchorage of the maxilloturbinate. This turbinate is continuous medially with the atrioturbinate (see below), forming the maxillo-atrioturbinates and occupying almost the anterior part of the nasal capsule (Figures 5-11). The dorsolaterally situated maxillo-atrioturbinates and the posteriorly situated ethmoturbinates (see below) are separated by a gap of $55 \mathrm{~mm}$.

Ossified solum nasi. The solum nasi, forming on each side the primary floor of the anterior region of the nasal capsule, is formed by a horizontal lamina extending laterally from the ventral border of the osseous septum nasi. The lateral end of the lamina bends dorsally to meet the paries nasi, forming there the osseous root of the atrioturbinate. This lamina possibly represents the processus lateralis ventralis and the lamina transversalis anterior of prenatal armadillos. According to Fawcett (1919, 1921), Reinbach (1952a, 1952b, 1955), Wegner (1960) and Zeller et al. (1993) the lamina transversalis anterior is united with the ventral border of the paries nasi and, at this contact, with the base of atrioturbinate.

Ossified septum nasi. The ossified nasal capsule is subdivided into right and left chambers by the septum nasi (Figure 5). In anterior view, the septum nasi is triangular, with its dorsal third grooved by a narrow depression (sulcus dorsalis: see Tec- tum nasi, above). Its ventral two thirds exhibit a rough surface, which served for attachment of the cartilaginous anterior part of the septum nasi. The septum rest on the vomer, but these elements are completely fused. As described for Zaedyus pichiy (Desmarest, 1804) and Dasypus novemcinctus Linnaeus, 1758 (Fawcett, 1919; Reinbach, 1955; Wegner, 1960), two lateral expansions are discernible from the middle portion of the septum that represent the septoturbinates (Figures 6, 9, 10). These turbinates are medially and slightly posteriorly disposed with respect to the maxillo-atrioturbinates and are separated from the ethmoturbinates by a gap of $50 \mathrm{~mm}$. The surface of the anterior margins of the ossified septum nasi and processus alaris superior is rough, suggesting that a considerable amount of soft tissues (connective and muscular) arose from these areas and formed the fleshy nostrils and the upper lip.

Nasal meatuses. The nasal meatuses (Figure 11) are air-flow passages within the nasal cavity (Evans, 1993). The meatus nasi dorsalis is located between the ventral surface of the ossified tectum nasi and the dorsal surface of the maxillo-atrioturbinates. This meatus is continuous laterally with the meatus nasi lateralis that is located between the lateral surface of the maxillo-atrioturbinates and the ossified paries nasi. This lateral air space is continuous with the meatus nasi ventralis, which is located between the ventral surface of the maxillo-atrioturbinates and the nasal cavity floor (dorsal surface of the hard palate). The meatus nasi dorsalis and ventralis are continuous with the meatus nasi communis, which is positioned between the ossified septum nasi and the medial-most surface of the maxillo-atrioturbinates. Finally, the meatus communis empties into the nasopharyngeal duct (see below).

Posterior portion. The posterior portion of the nasal cavity is delimited dorsally by the ventral surfaces of the nasals and frontals, anteriorly by the posteroventral border of the septoturbinates, posteriorly by the anterior surface of the cribriform plate, and ventrally and laterally by the palatine and maxillary (Figures 6, 10). The participation of the horizontal processes of the palatines to the floor of the nasal cavity could not be determined because the sutural contact with the maxilla is obliterated. Moreover, Gillette and Ray (1981) mentioned that this process is absent in the glyptodont Glyptotherium. Internally, the posterior nasal cavity is partitioned into an undivided anterior half, whereas the posterior half is divided by the pneumatized horizontal lamina transversalis. The latter 
forms the floor of the ethmoturbinal chamber and the roof of the posterior part of the nasopharyngeal duct that bears in its medial line two continuous grooves separated by a low septum. The fanshaped ethmoturbinates are continuous with the cribriform plate. This latter shows on the middle line of its encephalic surface a prominent and anterodorsally-posteroventrally sloped crista galli.

\section{DISCUSSION}

\section{Ossified Nasal Cartilages}

Despite the variation observed in the morphology of the ossified nasal cartilages among the different species assigned to Neosclerocalyptus (Figure 3 ), the presence of this structure in the adult stage is a feature not known for any other glyptodont, and not described for any extant terrestrial mammal.

The ossified nasal cartilages have been interpreted by Zurita (2002) and Zurita et al. (2005, $2008,2009,2011)$ as the most anterior part of the fronto-nasal sinuses system, and the entire system of paranasal sinuses was described as an autapomorphy of the genus. However, the clear osseous discontinuity between the most anterior portion of the narial region and the nasals, premaxillae and maxillae, and the triple nature of the osseous walls of this anterior narial region (a trabecular layer between two cortical layers), allows it to be considered as the independent ossification of the anterior portion of the nasal capsule. As mentioned above, the shape of the external surface of the ossified nasal cartilages allows recognition of two morphotypes: I, a single globular structure, and II, a globular structure with at least two protuberances separated by grooves. Among the species recognized by Zurita et al. (2011) the first morphotype is present in those specimens assigned to $N$. ornatus (MLP 16-28, AGM 006), N. gouldi (MCA 2010) and N. paskoensis (MLP 16-384, MACN-Pv 18107) and the second morphotype in specimens assigned to N. pseudornatus (MACN-Pv 8579) and Neosclerocalyptus sp. (MACN-Pv 8091).

Regarding the fact that the nasal capsule of extant cingulates remains cartilaginous at the adult stage (Starck, 1967; Wegner, 1922), the ossification of the nasal cartilages in Neosclerocalyptus would represent a neomorphic feature produced by a terminal addition of an ossified stage via peramorphosis (sensu Alberch et al., 1979). However, the absence of a fenestra lateralis in N. paskoensis does not allow us to assert that it is exclusively a terminal addition. Indeed, the absence of this fea- ture could be explained by two developmental hypotheses: 1) the nasal capsule of $N$. paskoensis developed as in modern cingulates, forming a fenestra lateralis, and this fenestra was obliterated during the process of ossification, and 2) the nasal capsule of $N$. paskoensis retained the condition of an earlier embryonic stage, prior to the formation of the fenestra lateralis, and this feature of the foetal nasal capsule in the adult was preserved by the subsequent ossification. The first hypothesis would corroborate the ossified condition as a terminal addition, whereas the second would imply another heterochronic process (paedomorphosis) in addition to the neomorphic ossification. Either of these two hypotheses requires an ontogenetic series to be tested.

\section{The Processus Alaris of the Nasal Cartilages}

One of the problems we faced during the development of this work was to establish an unequivocal nomenclature to designate different parts of the nasal cavity. This difficulty was particularly marked with respect to the number and position of the processus alaris, the interpretations of which vary considerably among the several authors who have studied the nasal region of armadillos.

Fuchs (1911) recognized the existence of two processes located at the anterior and posterior part of the lateral border of the fenestra narina in prenatal specimens of Dasypus novemcinctus. He could not decide whether these structures were homologous to the processus alaris superior and inferior observed in the lizard Lacerta (Gaupp, 1900) and the monotreme Echidna (Gaupp, 1908) because, in contrast to the condition in these taxa, Dasypus novemcinctus shows the processus superior and inferior in a lower and upper position, respectively, therefore he preferred to label them as anticus and posticus (Fuchs, 1911, p. 38). Later, Fawcett (1921) named Fuchs' cartilage alaris posticus and cartilage alaris antica as the processus alaris inferior and superior, respectively. This opinion was not shared by Reinbach (1952a, 1952b) and Wegner (1960), who recognized that the cartilage alaris antica of Fuchs (1911) and the processus alaris superior of Fawcett (1921) correspond to the folding of the lateral portion of the fenestra narina, and therefore, it is not a true process. Therefore, Reinbach (1952a, 1952b) and Wegner (1960), as well as Zeller et al. (1993) and Göbbel (2000), considered the processus alaris inferior of Fawcett as the processus alaris superior because it is continuous with the paries nasi. Thus, in this and future contri- 
butions, we follow Reinbach (1952a, 1952, 1955), Wegner (1960) and Zeller et al. (1993) with respect to the identification of prenatal structures of the anterior part of the nasal cartilage in considering the bony process arising from the ossified paries nasi in N. paskoensis as the processus alaris superior. This structure is also present in $N$. gouldi (MCA 2010), but absent in N. ornatus (MLP 16-28) and Neosclerocalyptus sp. (MACN-Pv 8091). In the remaining specimens this part of the skull is missing.

\section{Turbinates}

In relation to the identification of the turbinates, $N$. paskoensis had septoturbinates but lacked nasoturbinates. This absence was associated with the clear retraction of the nasal bones with respect to the nasal aperture, and concomitantly with the greater separation between anterior and posterior (ethmo) turbinates. Septoturbinates were described in prenatal individuals of the extant armadillo Zaedyus, but not in adults by Reinbach (1955). Wegner (1922) described osseous septoturbinates in adult specimens of the extant Cabassous. Adult specimens of both armadillos have a cartilaginous nasal capsule. Considering the case of Zaedyus, the presence of septoturbinates in $N$. paskoensis, could be related also to heterochronic processes, but regarding the presence of osseous septoturbinates in adults of Cabassous this hypothesis should be further explored. In any case, it is clear that retention of septoturbinates in the adult forms of both Neosclerocalyptus and Cabassous is independent of the presence or absence of neomorphic ossification of the nasal capsule. The extension of these conclusions to the other species of the genus implies particular descriptive studies for each morphotype (I and II), currently in progress.

\section{Nasal Cavity of Neosclerocalyptus and Function}

With regard to the function of the nasal cavity, we follow conceptualizations provided by Bock and von Wahlert (1965) and Plotnick and Baumiller (2000), who considered function as "what a feature does" (including both physical and chemical emergent properties of its form). The four main functions described for the nasal cavity in mammals correspond to chemoreception, hydric and thermal regulation, and the passage of air to the lungs (Craven et al., 2010).

Among extant terrestrial mammals, in the pig (Sus scrofa) the ventral and anterior end of the septum nasi usually ossifies, forming an "os narialis" (Getty, 1982) of unknown function. In some specimens of the Pleistocene sloth Megatherium americanum Cuvier, 1796, the septum nasi is ossified along its entire length (Bargo et al., 2006, figure 2.A), a pattern also present in glyptodonts such as Glyptodon, Panochthus, and Doedicurus (Figure 1.3, 1.4, 1.5, respectively). However, beside these particular cases, the degree of ossification of the nasal cartilages as seen in Neosclerocalyptus spp. has no homologues among other terrestrial mammals, even among those with more bizarre narial anatomy (Witmer et al., 1999; Clifford and Witmer 2004a, 2004b). Functional consequences of the neomorphic ossification of the nasal capsule described above are not readily predicted or inferred. Indeed, as we discuss below, the inferred functions of the internal structures of the nasal cavity are the same or similar to those of extant mammals. In this context, it is possible that the functions of the ossified nasal cartilage were similar to the nasal and maxillary bones in other mammals: that is, supporting and covering the inner structures of the nasal cavity (turbinates). Thus, although further research is needed, this neomorphic ossification would constitute a morphological novelty, but not a functional one.

In mammals, the ethmoturbinates are involved in chemoreception while the maxillo- and atrioturbinates are related to thermal and hydric regulation and air passage. As mentioned above, in $N$. paskoensis the maxillo-atrioturbinates are widely separated from the ethmoturbinates. They are housed in wide, globulose, anterior chambers ("turbinate chambers") formed by the ossified nasal cartilages. The incurrent airflow (Figure 12) moved to surround the maxillo-atrioturbinates inside the dorsolateral meatuses before being channeled into the nasopharyngeal duct. This pattern seems to be concordant with those described for other mammals (Craven et al., 2010) and it allows us to infer that the maxillo-atrioturbinates had the same function in $N$. paskoensis as in other mammals: to humidify and warm the incoming air. Outgoing air (Figure 13) also passed around the turbinates, in this case being dehumidified. As well, the incoming and outgoing air flowed through the septoturbinates: if the septoturbinates also had humidifying and warming functions, they surely would have participated with the maxillo-atrioturbinates in conditioning the air. The expanded rostral area of the maxillo-atrioturbinates of Neosclerocalyptus suggest increased capabilities for air conditioning when compared with other coetaneous glyptodonts 


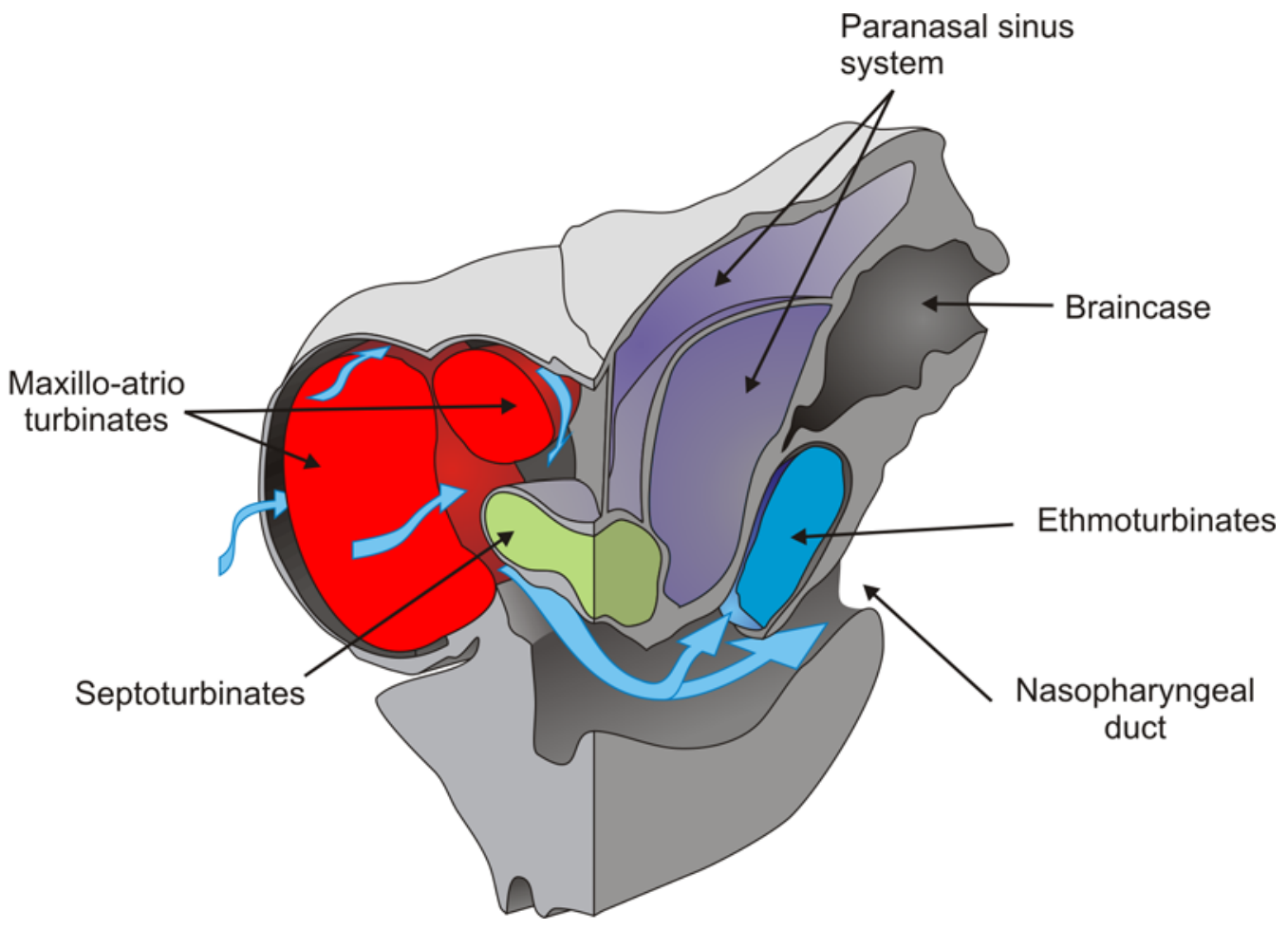

FIGURE 12. Neosclerocalyptus paskoensis (MACN-Pv 18107). Block diagram depicting structures explained in the text and inferred entering airflow (light blue arrows).

as Glyptodon, Panochthus and Doedicurus, at least in absence of ad hoc physiological hypotheses. These functional hypotheses have to be addressed by further, specific analysis such as morphometric approaches, to test allometric patterns, for instance.

Although the biological role of these functional properties are difficult to address, they suggest that Neosclerocalyptus would breathe more efficiently in coldest and/or dryer conditions than other glyptodonts. Despite its speculative nature, the behavioral explanatory hypothesis that in areas where it was sympatric with other glyptodonts Neosclerocalyptus expend more time grazing during moments of the day with lower temperatures (i.e., at night or dawn), can be proposed. Increased capabilities for air conditioning can also be related to metabolic requirements derived from higher activity patterns, e.g., a more cursorial or a more digging behavior, or a larger home-range than other glyptodonts.

The morphology of the ethmoid chamber of $N$. paskoensis allowed isolation of part of the airflow. Such a condition is termed macrosmatic, defined by Craven et al. (2010) as the condition where a lamina transversalis of the sphenoid bone prevents most of this air from being delivered to the lungs via the nasopharynx, and remaining quiescent, sur- rounding the ethmoturbinates even during the expiration, and optimizing chemoreception. Thus, the ethmoid chamber constitutes an "olfactory recess," which houses chemoreceptory turbinates and receives part of the airflow. This condition is also present in the modern relatives of glyptodonts, the armadillos. Morphometric studies are needed to assess differences in olfactory capabilities of $N$. paskoensis in comparison with other glyptodonts.

The paranasal sinus system has several hypothetical functions discussed largely by Witmer (1997, see references therein). These functions include not only increasing area for olfaction, humidification and warming of the inspired air, but also thermal insulation, vocal resonation, weight reduction, flotation and shock absorption, among others. The absence of wide fenestration allowing communication of the paranasal sinuses with the nasal cavity in $N$. paskoensis weakens the functional hypothesis for vocal resonation, olfaction and air conditioning. The possibility of thermal insulation requires more detailed research on extant cingulates in order to be evaluated. Farke's (2008, 2010) work on bovids and ceratopsians suggested that paranasal sinuses would be functionless structures resulting from removal of unnecessary bone (opportunistic pneumatization). Fariña and Viz- 


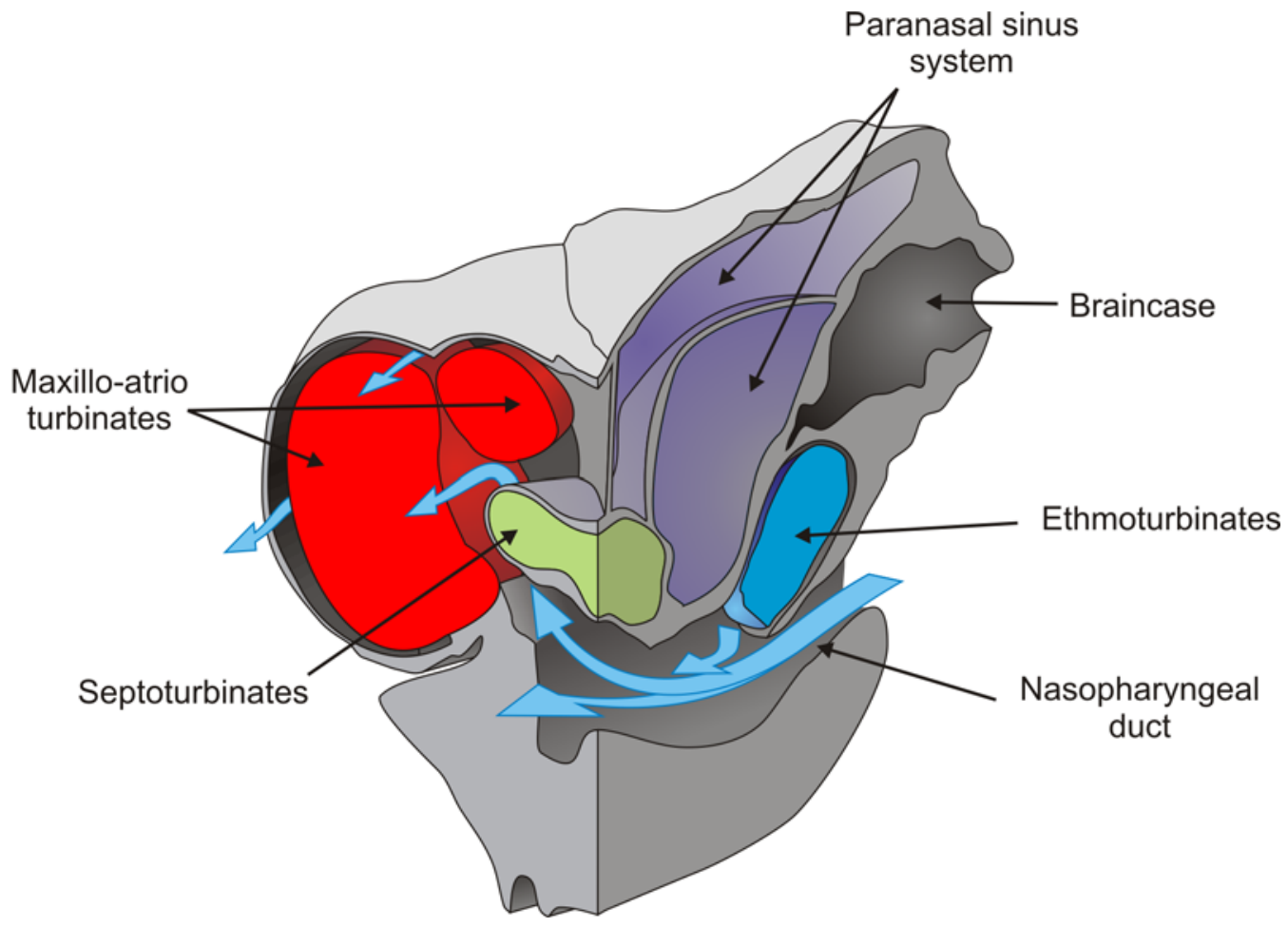

FIGURE 13. Neosclerocalyptus paskoensis (MACN-Pv 18107). Block diagram depicting structures explained in the text and inferred leaving airflow (light blue arrows).

caíno (2001) addressed that the telescoping process that displaced the masticatory apparatus of glyptodonts beneath the cranium could reduce the moment of the weight of head, compensating the relatively small space left by the dorsal carapace for neck muscles supporting and counterbalancing the head. In agreement with this, the extensive pneumatization of the skull roof in $N$. paskoensis could help to reduce the density of the skull roof. However, more testing of the proposed functions on weight reduction in N. paskoensis is needed for further and more detailed studies. Zurita et al. (2011) suggested a correlation between the degree of development of the paranasal sinus system in Neosclerocalyptus and the cold arid Pleistocene cycles of South America (Clapperton, 1993), but the structures they identified as paranasal sinuses are in fact ossified nasal cartilages (see above). Nevertheless, following Witmer's (1997) and Farke's (2010) discussion of several of these functional hypotheses, it is clear that the function of the paranasal sinuses in the terrestrial vertebrates remains enigmatic, hindering making predictions about their biological role in the ecology of $\mathrm{NeO}$ sclerocalyptus until more detailed studies are performed, particularly on extant cingulates.
In summary, the inferred functions of the various structures forming the nasal cavity of $N$. paskoensis are broadly similar to those of extant mammals: support and protection of the nasal cavity, conditioning of inspired and expired air, and chemoreception. However, this strict actualistic criterion may be of restricted use when phylogenetic affinity is not very close or fossil lineages possess morphologies not represented in extant species, what is clearly the case for xenarthans in general and glyptodonts in particular. Due to the historical contingency of evolutionary constraint, if a lineage develops a phenotype that is adapted to a certain environmental condition, its species will not necessarily be identical to the current models. This circumstance is particularly applicable to those mammalian faunas that evolved in isolation in South America during the Cenozoic. Among them, xenarthrans show important dental, skeletal, and muscular peculiarities that make them differ greatly from other mammals (Vizcaíno and De luliis, 2003; Vizcaíno et al., 2004; Vizcaíno et al., 2008).

\section{CONCLUDING REMARKS}

The skull of Neosclerocalyptus (and particularly the species $N$. paskoensis) described here possesses a markedly different nasal cavity com- 
pared to that of other glyptodont genera. The unusual organization of the nasal cavity of $N$. paskoensis includes a wide separation between anterior (maxillo-atrio) turbinates and posterior (ethmo) turbinates, the absence of nasoturbinates, the development of a highly pneumatized skull, and the independent and derived condition of ossification of the nasal cartilages. The maxilla-atrioturbinates are circumscribed medially, dorsally and laterally by the ossified anterior nasal capsule, the external borders of which are not covered by the nasals, premaxillae or maxillae.

The following summarizes the most important conclusions of this study:

A detailed revision of a number of skulls assigned to different glyptodonts drew attention to several skulls with well-marked bony limits that permit the identification of previously undescribed bony elements.

The most notable differences between Neosclerocalyptus and the remaining glyptodonts is the existence of an anterior ossification, which corresponds to the anterior portion of the cartilaginous nasal capsule. The macroscopic analysis of this element reveals that its structure is composed of three bony layers. The external and internal are compact, and the middle layer is trabecular in aspect. Together with the clear discontinuity with the nasals, premaxillae and maxillae, these features indicate that this element is an independent, possibly endochondral, ossification. This ossification houses the maxillo-atrioturbinals.

The shape of the external surface of the ossified nasal cartilages exhibits two morphotypes: I, a single globular structure, and II, a globular structure with at least two protuberances separated by grooves.

Marked pneumatization is present in almost all cranial bones, which modifies to a great extent the internal structure of the nasal cavity. However, the function of these inner air cavities remains enigmatic, although it could be related to weight reduction.

Analysis of the morphology of the nasal cavity suggests that functions of its elements were very similar to those described for extant terrestrial mammals. Functional hypotheses concerning the paranasal sinuses could not be assessed; their evaluation requires further studies. A paleobiological hypothesis, albeit requiring further studies, is that $N$. paskoensis could have breathed more efficiently than other coetaneous glyptodonts in coldest and/or dryer conditions.

\section{ACKNOWLEDGMENTS}

We are especially grateful to R.A. Alvarez del Rivero and O. Salvador of the Unidad Tomografía Computada at the Hospital Interzonal de Agudos de la Matanza "Dr. Diego Pairoissien" (La Matanza, Argentina) for providing access to CT facilities and assistance with $C T$ scanning. We thank $M$. Reguero (MLP), and A. Kramarz (MACN) who kindly gave us access to the specimens under their care; G. De luliis for valuable suggestions that improved the manuscript and to the two anonymous reviewers that helped to enhance our work. This is a contribution to the grants, PICT 0143, UNLP N 647 and PIP-CONICET 1054 to Sergio F. Vizcaíno and UNLu CDD-CD 281-09 to Juan Carlos Fernicola.

\section{REFERENCES}

Alberch, P., Gould, S.J., Oster, G.F., and Wake, D.B. 1979. Size and shape in ontogeny and phylogeny. Paleobiology, 5:296-317.

Ameghino, F. 1887. Enumeración sistemática de las especies de mamíferos fósiles coleccionados por Carlos Ameghino en los terrenos eocenos de Patagonia Austral y depositados en el Museo de La Plata. Boletín del Museo de La Plata 1-26.

Ameghino, F. 1889. Contribución al conocimiento de los mamíferos fósiles de la República Argentina. Actas Academia Nacional de Ciencias en Córdoba, 6:11027.

Bargo, M.S., Toledo, N., and Vizcaíno, S.F. 2006. Muzzle of South American Pleistocene ground sloths (Xenarthra, Tardigrada). Journal of Morphology, 267:248263.

Bock, W.J. and Von Wahlert, G. 1965. Adaptation and the form-function complex. Evolution, 19:269-299.

Burmeister, H. 1866. Lista de los mamíferos fósiles del terreno diluviano. Anales del Museo Público de Buenos Aires, 1:121-232.

Burmeister, H. 1870-74. Descripción del género Hoplophorus. Monografía de los Gliptodontes en el Museo Público de Buenos Aires. Anales del Museo Público de Buenos Aires, 2:1-412.

Clapperton, C. 1993. Nature of environmental changes in South America at the Last Glacial Maximum. Palaeogeography Palaeoclimatology and Palaeoecology, 101:189-208.

Clifford, A.B. and Witmer, L.M. 2004a. Case studies in novel narial anatomy. 2. The enigmatic nose of moose (Artiodactyla: Cervidae: Alces alces). Journal of Zoology London, 262:339-360.

Clifford, A.B. and Witmer, L.M. 2004b. Case studies in novel narial anatomy. 3. Structure and function of the nasal cavity of saiga (Artiodactyla: Bovidae: Saiga tatarica). Journal of Zoology London, 264:217-230. 
Craven, B.A., Paterson, E.G., and Settles, G.S. 2010. The fluid dynamics of canine olfaction: unique nasal airflow patterns as an explanation of macrosmia. Journal of the Royal Society, Interface, 7:933-943.

Cruz, L.E., Fernicola, J.C., Carignano, C.A., and Bargo, M.S. in press. Asociaciones faunísticas del Cuaternario de San Francisco, provincia de Córdoba, Argentina. Implicancias bioestratigráficas y taxonómicas. Ameghiniana.

Cuvier, G. 1796. Notice sur le squelette d'une tresgrande espece de quadrupede inconnue jusqu'a present, trouve au Paraquay, et depose au cabinet d'histoire naturelle de Madrid. Magasin Encyclopèdique: ou Journal des Sciences, des Lettres et des Arts, 1:303-312.

De Esteban-Trivigno, S., Mendoza, M., and De Renzi, M. 2008. Body mass estimation in Xenarthra: A predictive equation suitable for all quadrupedal terrestrial placentals? Journal of Morphology, 269:1276-1293.

Desmarest, A.G. 1804. Tableau Méthodique des Mammifères in Nouveau Dictionnaire d'Histoire Naturelle, Appliquée aux Arts, Principalement à l’Agriculture, à l'Économie Rurale et Domestique: Par une Société de Naturalistes et d’Agriculteurs: Avec des ures Tirées des Trois Règnes de la Nature. Deterville (Volume 24), Paris.

Evans, H.E. 1993. Miller's Anatomy of the Dog (third edition). W.A. Saunders Company. Philadelphia.

Fariña, R.A. and Vizcaíno, S.F. 2001. Carved teeth and strange jaws: how glyptodonts masticated. Acta Paleontologica Polonica (Special Issue), 46:87-102.

Fariña, R,A., Vizcaíno, S.F., and Bargo, M.S. 1998. Body size estimations in Lujanian (Late Pleistocene-Early Holocene of South America) mammal megafauna. Mastozoología Neotropical, 5:87-108.

Farke, A.A. 2008. Function and evolution of the cranial sinuses in bovid mammals and ceratopsian dinosaurs. Unpublished PhD Thesis, Stony Brooks University, New York, USA.

Farke, A.A. 2010. Evolution and functional morphology of the frontal sinuses in Bovidae (Mammalia: Artiodactyla), and implications for the evolution of cranial pneumaticity. Zoological Journal of the Linnean Society, 159:988-1014.

Fawcett, E. 1919. The os septo-maxillare of Tatusia novemcincta. Journal of Anatomy, 53:349-350.

Fawcett, E. 1921. The primordial cranium of Tatusia novemcincta as determined by sections and models of $12 \mathrm{~mm}$ and $17 \mathrm{~mm} \mathrm{C}$. R. length. Journal of Anatomy, 55:187-217.

Fernicola, J.C. 2008. Nuevos aportes para la sistemática de los Glyptodontia Ameghino 1889 (Mammalia, Xenarthra, Cingulata). Ameghiniana, 45:553-574.

Fernicola, J.C. and Porpino, K.O. 2012. Exoskeleton and systematics: A historical problem in the classification of Glyptodonts. Journal of Mammalian Evolution, 19:171-183.
Fernicola, J.C., Vizcaíno, S.F., and Fariña, R. 2008. The evolution of armored xenarthrans and a phylogeny of the glyptodonts, p. 79-85. In Vizcaíno, S.F. and Loughry, W.J. (eds.), The Biology of the Xenarthra. University Press of Florida, Gainesville.

Fernicola, J.C., Toledo, N., Vizcaíno, S.F., and Bargo, M.S. 2007. A peculiar ossification of the skull of $\mathrm{NeO}-$ sclerocalyptus Paula Couto, 1957 (Mammalia: Cingulata: Glyptodontidae). Journal of Morphology, 268:1073.

Fernicola, J.C., Toledo, N., Vizcaíno, S.F., and Bargo, M.S. 2010. The nasal cavity of Neosclerocalyptus Paula Couto 1957 (Mammalia Xenarthra Glyptodontia). IX International Congress of Vertebrate Morphology. DVD support.

Fuchs, H. 1911. Ueber das Septomaxillare eines rezenten Säugetieres (Dasypus), nebst einigen vergleichend-anatomischen Bemerkungen über das Septomaxillare und Praemaxillare der Amnioten überhaupt. Anatomischer Anzeiger, 38:33-55.

Gaudin, T.J. and Wible, J.R. 2006. The phylogeny of living armadillos (Mammalia, Xenarthra, Cingulata): A craniodental analysis, p. 153-198. In Carrano, M.T., Gaudin, T.J., Blob, R.W., and Wible, J.R. (eds.), Amniote Paleobiology. Perspectives on the Evolution of Mammals, Birds and Reptiles. University of Chicago Press, Chicago.

Gaupp, E. 1900. Das Chondrocranium von Lacerta agilis: Ein Beitrag zum Verständnis des Amniotenschädels. Anatomische Hefte, 15:433-595.

Gaupp, E. 1908. Zur Entwicklung und vergleichenden Morphologie des Schädels von Echidna aculeata var. typica. Semons zoologische Forschungreisen in Australien, 6:539-788.

Gavrilov, K. 1959. Curso de anatomía y fisiología comparadas. IV esqueleto. Escuela Universitaria de Ciencias Naturales, Universidad Nacional de Tucumán, Tucumán.

Getty, R. 1982. Sisson and Grossman: Anatomía de los animales domésticos. II: Porcinos, Carnívoros and Aves. Salvat, Barcelona.

Gillete, D.D. and Ray, C.E. 1981. Glyptodonts of North America. Smithsonian Contributions to Paleobiology, 40:1-255.

Göbbel, L. 2000. The external nasal cartilages in Chiroptera: Significance for intraordinal relationships. Journal of Mammalian Evolution, 7:167-201.

Hoffstetter, R. 1958. Xenarthra, p. 535-636. In Piveteau, J. (ed.), Traité de Paléontologie, (Volume 2). Masson and Cie., Paris.

Huxley, T.H. 1864. On the osteology of the genus Glyptodon. Proceedings of the Royal Society of London, 13:31-70.

Kalthoff, D.C. 2011. Microstructure of dental hard tissues in fossil and recent xenarthrans (Mammalia, Folivora and Cingulata). Journal of Morphology, 272:641-661. 
Linnaeus, C. 1758. Systema Naturae per Regna Tria Naturae, secundum Classes, Ordines, Genera, Species, cum Characteribus, Differentiis, Synonymis, Locis. Tomus I (Editio decima). Laurentii Salvii, Holmiae, Stockholm.

Lund, P.W. 1839. Blik paa Brasiliens dyreverden för sidste jorgdomvaeltning. Anden afhandling: Pattedyrene (Lagoa Santa d. 16 de novbr. 1837). Det Kongelige Danske Videskabernes Selskabs Naturvidenskabelige og Mathematiske Afhandlinger 8:61-144.

Márquez, S., Tessema, B., Clement, P.A.R., and Schaefer, S.D. 2008. Development of the ethmoid sinus and extramural migration: the anatomical basis of this paranasal sinus. The Anatomical Record, 291:1535-1553.

McKenna, M.C. and Bell, S.K. 1997. Classification of Mammals above the Species Level. Columbia University Press, New York.

Osborn, H.F. 1903. Glyptotherium texanum, a new glyptodont, from the Lower Pleistocene of Texas. Bulletin of the American Museum of Natural History, 19:491494.

Owen, R. 1839. Description of a tooth and part of the skeleton of the Glyptodon, a large quadruped of the edentate order, to which belong the tessellated bony armour figured by Mr. Clift in his memoir on the remains of the Megatherium, brought to England by Sir Woodbine Parish, F. G. S. Proceedings of the Geological Society, 3:108-113.

Owen, R. 1845. Descriptive and illustrated catalogue of the fossil organic remains of Mammalia and Aves contained in the Museum of the Royal College of Surgeons of England. Taylor, R. and Taylor, J.E. London.

Paula Couto, C. 1957. Sôbre um gliptodonte do Brasil. Departamento Nacional de Produção Mineral, Divisão de Geologia e Mineralogia, Rio de Janeiro.

Plotnick, R.E. and Baumiller, T.K. 2000. Invention by evolution: functional analysis in paleobiology. Paleobiology (Supplement to $\mathrm{N}^{\circ} 4$ ), 26:305-321.

Porpino, K.O., Fernicola, J.C. and Bergqvist, L.P. 2010. Revisiting the intertropical Brazilian species Hoplophorus euphractus (Cingulata, Glyptodontoidea) and the phylogenetic affinities of Hoplophorus. Journal of Vertebrate Paleontology, 30:911-927.

Reinbach, W. 1952a. Zur Entwicklung des Primordialcraniums von Dasypus novemcinctus Linné (Tatusia novemcinctus Lesson) I. Zeitschrift für Morphologie und Anthropologie, 44:375-444.

Reinbach, W. 1952b. Zur Entwicklung des Primordialcraniums von Dasypus novemcinctus Linné (Tatusia novemcincta Lesson) II. Zeitschrift für Morphologie und Anthropologie, 45:1-72.

Reinbach, W. 1955. Das Cranium eines Embryos des Gürteltieres Zaedyus minutus (65 mm Sch.- St.). Gegenbaurs Morphologisches Jahrbuch, 95:79-141.
Scott, W.B. 1903. Mammalia of the Santa Cruz Beds. Volume V, Paleontology. Part I, Edentata. 2. Glyptodonta and Gravigrada, p. 107-227. In Scott, W.B. (ed.), Reports of the Princeton University Expeditions to Patagonia, 1896-1899. Princeton University, E. Schweizerbart'sche Verlagshandlung (E. Nägele), Stuttgart.

Starck, D. 1967. Le crane des mammifères, p. 405-549. In Grassé, P.-P. (ed.) Traité de zoologie: anatomie, sistématique, biologie, XVI (I) Mammifères, téguments, squelette. Masson et Cie., Paris.

Toledo, N., Fernicola, J.C., Bargo, M.S., and Vizcaíno, S.F. 2007. Reconstrucción de la musculatura facial anterior de Neosclerocalyptus Paula Couto, 1957 (Mammalia: Cingulata: Glyptodontidae). Ameghiniana, 44(4):41R.

Vizcaíno, S.F. 2009. The teeth of the "toothless": novelties and key innovations in the evolution of xenarthrans (Mammalia, Xenarthra). Paleobiology, 35:343366.

Vizcaíno, S.F. and De luliis, G. 2003. Evidence for advanced carnivory in fossil armadillos (Mammalia: Xenarthra: Dasypodidae). Paleobiology, 29:123-38.

Vizcaíno, S.F., Bargo, M.S., and Fariña, R.A. 2008. Form, function, and paleobiology in xenarthrans, $p$. 86-99. In Vizcaíno, S.F. and Loughry, W.J. (eds.), The biology of the Xenarthra, University Press of Florida, Gainesville.

Vizcaíno, S.F., Blanco, R.E., Bender, J.B., and Milne, N. 2011a. Proportions and function of the limbs of glyptodonts (Mammalia, Xenarthra). Lethaia, 44:93-101.

Vizcaíno, S.F., Cassini, G.H., Fernicola, J.C., and Bargo, M.S. 2011b. Evaluating habitats and feeding habits through ecomorphological features in glyptodonts (Mammalia, Xenarthra). Ameghiniana, 48:305-319.

Vizcaíno, S.F., Cassini, G.H., Toledo, N., and Bargo, M.S. 2012. On the evolution of large size in mammalian herbivores of Cenozoic faunas of South America, p. 76-101. In Patterson, B. and Costa, L. (eds.), Bones, clones and biomes: the history and geography of Recent Neotropical mammals, University of Chicago Press, Chicago.

Vizcaíno, S.F., Fariña, R.A., Bargo, M.S., and De luliis, G. 2004. Functional and phylogenetic assessment of the masticatory adaptations in Cingulata (Mammalia, Xenarthra). Ameghiniana, 41:651-664.

Wegner, G. 1960. Das Primordialcranium des Gürteltieres Dasypus novemcinctus Linné (Tatusia novemcinctus Lesson) von $14 \mathrm{~mm}$ Scheitel-Steifi-Länge. Zeitschrift für Morphologie und Anthropologie, 50:317-348.

Wegner, R.N. 1922. Der Stützknochen, Os nariale. in der Nasenhöhle bei den Gürteltieren, Dasypodidae, und seine homologen Gebilde bei Amphibien, Reptilien und Monotremen. Gegenbaurs Morphologisches Jahrbuch, 51:413-584. 
Wible, J.R. and Gaudin, T.J. 2004. On the cranial osteology of the yellow armadillo Euphractus sexcinctus (Dasypodidae, Xenarthra, Placentalia). Annals of Carnegie Museum, 73:117-196.

Witmer, L.M. 1997. The evolution of the antorbital cavity of archosaurs: A study in soft-tissue reconstruction in the fossil record with an analysis of the function of pneumaticity. Journal of Vertebrate Paleontology, 17:1-73.

Witmer, L.M., Sampson, S.D., and Solounias, N. 1999. The proboscis of tapirs (Mammalia: Perissodactyla): a case study in novel narial anatomy. Journal of Zoology London, 249:249-267.

Zeller, U., Wible, J.R., and Eisner, M. 1993. New ontogenetic evidence on the septomaxilla of Tamandua and Choloepus (Mammalia, Xenarthra), with a reevaluation of the homology of the mammalian septomaxilla. Journal of Mammalian Evolution, 1:31-46.

Zurita, A.E. 2002. Nuevo gliptodonte (Mammalia, Glyptodontoidea) del Cuaternario de la provincia del Chaco (Argentina). Ameghiniana, 39:175-183.
Zurita, A.E., Carlini, A.A., and Scillato-Yané, G.J. 2008. A new species of Neosclerocalyptus Paula Couto, 1957 (Xenarthra, Glyptodontidae, Hoplophorinae) from the middle Pleistocene of the Pampean region, Argentina. Geodiversitas, 30:779-791.

Zurita, A.E., Carlini, A.A., and Scillato-Yané, G.J. 2009. Paleobiogeography, biostratigraphy and systematics of the Hoplophorini (Xenarthra, Glyptodontoidea, Hoplophorinae) from the Ensenadan Stage (early Pleistocene to early-middle Pleistocene). Quaternary International, 210:82-92.

Zurita, A.E., Scillato-Yané, G.J., and Carlini, A.A. 2005. Paleozoogeographic, biostratigraphic, and systematic aspects of the Genus Sclerocalyptus Ameghino, 1891 (Xenarthra, Glyptodontidae) of Argentina. Journal of South American Earth Sciences, 20:121-129.

Zurita, A.E., Scarano, A.C., Carlini, A.A., Scillato-Yané, G.J., and Soibelzon, E. 2011. Neosclerocalyptus spp. (Cingulata: Glyptodontidae: Hoplophorini): cranial morphology and palaeoenvironments along the changing Quaternary. Journal of Natural History, 45(15-16):893-914. 